\title{
Microorganisms populating the water-related indoor biome
}

\author{
Monika Novak Babič ${ }^{1}$ (D) Cene Gostinčar ${ }^{1,2} \cdot$ Nina Gunde-Cimerman ${ }^{1}$
}

Received: 2 April 2020 /Revised: 22 May 2020 / Accepted: 2 June 2020 / Published online: 12 June 2020

(C) The Author(s) 2020

\begin{abstract}
Modernisation of our households created novel opportunities for microbial growth and thus changed the array of microorganisms we come in contact with. While many studies have investigated microorganisms in the air and dust, tap water, another major input of microbial propagules, has received far less attention. The quality of drinking water in developed world is strictly regulated to prevent immediate danger to human health. However, fungi, algae, protists and bacteria of less immediate concern are usually not screened for. These organisms can thus use water as a vector of transmission into the households, especially if they are resistant to various water treatment procedures. Good tolerance of unfavourable abiotic conditions is also important for survival once microbes enter the household. Limitation of water availability, high or low temperatures, application of antimicrobial chemicals and other measures are taken to prevent indoor microbial overgrowth. These conditions, together with a large number of novel chemicals in our homes, shape the diversity and abundance of indoor microbiota through constant selection of the most resilient species, resulting in a substantial overlap in diversity of indoor and natural extreme environments. At least in fungi, extremotolerance has been linked to human pathogenicity, explaining why many species found in novel indoor habitats (such as dishwasher) are notable opportunistic pathogens. As a result, microorganisms that often enter our households with water and are then enriched in novel indoor habitats might have a hitherto underestimated impact on the well-being of the increasingly indoor-bound human population.
\end{abstract}

\section{Key points}

- Domestic environment harbours a large diversity of microorganisms.

- Microbiota of water-related indoor habitats mainly originates from tap water.

- Bathrooms, kitchens and household appliances select for polyextremotolerant species.

- Many household-related microorganisms are human opportunistic pathogens.

Keywords Household microbiome $\cdot$ water-borne $\cdot$ bacteria $\cdot$ fungi $\cdot$ extremophiles $\cdot$ opportunists

\section{Introduction}

The world we live in is rapidly changing. Clean and safe water is an indispensable resource that is becoming increasingly scarce as the world population is growing, consumption as well as pollution is going up, urbanisation is spreading and mega cities became the new ecological reality. People from developed societies now spend approximately $90 \%$ of their

Nina Gunde-Cimerman

nina.gunde-cimerman@bf.uni-lj.si

1 Department of Biology, Biotechnical Faculty, University of Ljubljana, Jamnikarjeva 101, 1000 Ljubljana, Slovenia

2 Lars Bolund Institute of Regenerative Medicine, BGI-Qingdao, Qingdao 266555, China lives indoors (Kelley and Gilbert 2013). This increases their exposure to indoor microorganisms, the diversity and abundance of which can differ profoundly from natural environments or even human dwellings of the past. Some of these microorganisms can cause allergies and infectious diseases, in particular in immunocompromised, chronically ill, or elderly individuals as well as infants (de Hoog et al. 2014).

Microorganisms enter buildings with outdoor air, soil, water, living plants and different food products as well as other humans and pets (Weikl et al. 2016; Jayaprakash et al. 2017; Shan et al. 2019; Cooper 2010). Most published overviews of indoor microbiomes focus on air-borne, dust-associated microbes (Shan et al. 2019). Comparatively little has been published on microbes in domestic water sources or in wet or humid domestic environments such as kitchens, bathrooms and domestic appliances, containing or operating with water. 
In this review, we will therefore mainly focus on this subject, limiting the overview of air-borne, dust-associated microbiome research to a brief summary.

Indoor dust includes fungal conidia and spores, spore fragments, dead and living bacterial cells, their fragments, endospores and other spores. Thus, up to 500-1000 different species can be present in house dust (Rintala et al. 2012). Cultureindependent methods indicate that the house dust bacterial community is dominated by Gram-positive bacteria, especially Firmicutes and Actinobacteria. These bacteria originate primarily from human-associated sources (Hanson et al. 2016; Noris et al. 2011; Rintala et al. 2008; Taubel et al. 2009). Fungi can also be present in dust in great numbers. Thus, standard fungal cultivation methods showed up to 70 million CFU/g of dust (Beguin and Nolard 1996). Such dustassociated fungi are typically related to the outside environment (Shan et al. 2019). Although the most cosmopolitan fungal taxa are common everywhere, the latitude and season influence their indoor diversity. In general, these dust-related fungal communities are more diverse in comparison with the bacterial indoor biome (Dannemiller et al. 2016). The composition of these indoor microbial communities is associated with the levels of urbanisation and the health of the inhabitants, in particular concerning allergic disorders, intestinal microbiome and general immune responses (Shan et al. 2019).

Water availability is a major requirement for microbial growth. Indoor water-borne microorganisms are not confined only to bathrooms and kitchens but can also populate tap water systems and household appliances, in which they can be attracted to certain chemicals and plastic or rubber surfaces. These conditions are not conductive to growth of most microorganisms; however, some adapted microbes, and in particular fungi, are able to metabolise phenols and hydrocarbons (Prenafeta-Boldu et al. 2006) and are generally very adaptable, resilient and in some cases also thermotolerant (Gostinčar et al. 2011, 2015; Zalar et al. 2011; Zupančič et al. 2016). Additionally, as a side effect of attempts to improve the energy-efficiency and environmental friendliness of household appliances, these became more prone to microbial growth. Already in 1999, Beadle and Verran stated that lower temperatures for washing and less aggressive detergents without bleach became commonly used (Beadle and Verran 1999). While becoming more permissive, these conditions are still harsh enough to select for the more stress-resistant, but also often, virulent microbes, with greater potential to cause opportunistic human infections (Byrd-Bredbenner et al. 2013; Callewaert et al. 2015; Döğen et al. 2013a, b; Dunn et al. 2013; Gümral et al. 2016; Gostinčar et al. 2011, 2015; Raghupathi et al. 2018; Rehberg et al. 2017; Sasahara et al. 2011; Ståhl Wernersson et al. 2004; Zalar et al. 2011; Zupančič et al. 2016, 2018).

Research on water-related indoor microorganisms so far mostly focused on bacteria important for human health
(Larsen et al. 2010). Over the last 10 years, however, it became apparent that fungi occupy several wet or humid domestic niches exemplified by home appliances such as dishwashers and washing machines. The diversity of these fungal "water-biomes" turned out to be dominated by polyextremotolerant, oligotrophic species, some of which are opportunistic human pathogens, representing a potential health problem that became widely recognised only in the last years (Zalar et al. 2011; Hamada and Abe 2010; Lian and de Hoog 2010; Defra 2011; Fouquier et al. 2016). Therefore, this review will focus in particular on the diversity of polyextremotolerant fungi in domestic wet environments, and some evolutionary aspects of their adaptive abilities as well as their pathogenic potential.

\section{Water as a transmission vector of indoor microorganisms}

Before being suitable for water consumption, raw water originating from either surface water or groundwater is subjected to a variety of physico-chemical treatments in order to remove larger particles and microorganisms. The efficiency of removing microbes from raw water greatly depends on the combination of the cleaning techniques used and may vary between 8 and 99.99\% (WHO 2011). Water for human consumption should not contain potentially harmful microorganisms or dangerous substances, making it necessary to control not only the input water quality, but also the formation of biofilms and increases of the microbial load in the distribution system. Global requirements, directives and recommendations, which are the basis for other acts and standards, are currently directed by the World Health Organisation (WHO). Since WHO follows microbiological trends and health problems on a global level, they list a large spectrum of microbial genera that are important for monitoring water quality and thus ensuring public health (WHO 2011). The mandatory microbiological parameters used for the determination of water quality in the $\mathrm{EU}$ are the presence of the bacteria Escherichia coli, Clostridium perfringens, Pseudomonas aeruginosa, coliforms and the total number of detectable aerobic microorganisms after incubation at $22{ }^{\circ} \mathrm{C}$ and $37{ }^{\circ} \mathrm{C}$ (EEC 1998). Enteric viruses and occurrence of oocysts and cysts belonging to the protozoa Giardia lamblia, Cryptosporidium spp. and Entamoeba hystolitica can also be used as additional indicators of water quality, recommended by WHO (WHO 2011). Similarly within the EU, the United States Environmental Protection Agency (US EPA) issued the National Primary Drinking Water Regulations, but with some differences from the EU Drinking Water Directive 98/83/EC. For example, US EPA determines the limits for heterotrophic plate count, total coliforms, Cryptosporidium, Giardia lamblia, Legionella, Mycobacterium and enteric viruses (US EPA 2009, 2018). 


\section{Eukaryotic (micro) organisms in drinking water are often neglected}

Despite routine monitoring of several microbial parameters in water, these often do not cover spore-forming microorganisms and microbes aggregating in clumps. This can be seen as problematic, since such microorganisms are typically more resistant to the water treatment process and enter households via plumbing systems, where they are the cause of significant problems related to accumulation of biofilms and corrosion of materials. If present in large quantities, they also change the odour of water and may affect human health via toxin production (Novak Babič et al. 2017a, b).

Water is the main transmission medium of algae. Due to the need for light, algae can be found in the upper layers of natural water sources, particularly in lakes and rivers with low water flow (Wurzbacher et al. 2011). Some algal species belonging to the genera Scenedesmus, Euglena, Anacystis, Coelastrum, Prototheca and Chlorococcum can be found in tap water systems, despite chlorination, and can survive without light (Defra 2011). They contribute to the primary production of oxygen and biomass representing food for other microorganisms. Algae in tap water systems are particularly problematic as reservoirs of certain bacteria (e.g. Legionella). This phenomenon has been observed in genera Elakatothrix, Gomphosphaeria, Closterium, Cosmarium and Chlorella (Defra 2011). According to the WHO, algae producing toxins, and those causing bad taste or odour, should be absent from tap water (WHO 2011).

Water is the main transmission medium not only of algae but also of protists. Protists, particularly species from the genera Acanthamoeba, Naegleria, Saccamoeba, Hartmannella and Vexillifera, control the number of bacteria and to a lesser extent also of fungi (Defra 2011; Percival et al. 2014). Like algae, some represent hosts for pathogenic bacteria of the genera Legionella, Burkholderia and Mycobacterium. Additionally, species from the genera Cryptosporidium, Microsporidia and Giardia can act as human pathogens, causing diarrhoea, nausea, keratitis and encephalitis. Species that can form oocysts represent particular problems, since they are less sensitive to water chlorination (Valster 2011). According to the WHO Acanthamoeba spp., Cryptosporidium hominis, C. parvum, Cyclospora cayetanensis, E. histolytica, Giardia intestinalis and Naegleria fowleri should be absent from water. Monitoring of Balantidium coli, Blastocystis hominis, Isospora belli, Toxoplasma gondii and Microsporidia is also suggested (WHO 2011).

The least investigated group of eukaryotes with poorly understood roles in the water microbiome are fungi. Some species such as Candida parapsilosis, Penicillium spp. and Aspergillus spp. can represent a scaffold for microbial attachment (Zupančič et al. 2019; Richardson and RautemaaRichardson 2019; Fernandes et al. 2019) and food for protozoa (Defra 2011). Mainly, filamentous fungi also contribute to the formation of biofilms by cross-linking particulate matter and microbial polymers with hyphae (Richardson and Rautemaa-Richardson 2019; Fernandes et al. 2019). Biofilms in tap water systems may contain up to $8.9 \mathrm{CFU} / \mathrm{cm}^{2}$ of yeasts and 4.0-25.2 CFU $/ \mathrm{cm}^{2}$ of filamentous fungi (Doggett 2000). A great variety of fungi was detected in drinking water either by culture-dependent or molecular methods (e.g. with metagenome of amplicon sequencing). Their diversity significantly depends on the source of raw water (Moat et al. 2016; Novak Babič et al. 2017a, b). Water from surface water sources is dominated by plant-degrading fungi of the genera Acremonium, Altenaria, Arthrinium, Aspergillus, Beauveria, Botrytis, Cladosporium, Cryptococcus, Epicoccum, Fusarium, Geotrichum, Gliocladium, Mucor, Paecilomyces, Penicillium, Phoma, Rhizopus, Rhodotorula, Sporothrix and Trichoderma. Yeasts Candida spp., Cystobasidium spp. and black yeast-like fungi Aureobasidium, Cladophialophora, Cyphellophora, Exophiala, Phialophora and Rhinocladiella are more often found in water originating from the groundwater (Novak Babič et al. 2017a, b). Due to the lack of information linking clinical infections and the fungal presence in drinking water, fungi are not yet considered an independent parameter in water regulations. However, their presence in drinking water can alter the taste and odour of water, while in higher numbers they can impair human health causing allergies, asthma and superficial infections of hair, skin and nails (Defra 2011; Novak Babič et al. 2017a, b).

\section{Bacteria in water microbiome-still a great mystery?}

Bacteria are the most numerous microorganisms in tap water and biofilms of the water distribution system. Since the 18th century, people are aware of transmission of faecal bacteria via the plumbing system (Percival et al. 2014). In inappropriately treated water sources, after natural disasters or due to faults in water supply systems, the number of pathogenic bacteria involved in infections of the digestive and respiratory tract can exceed the prescribed safe limits (Percival et al. 2014). The presence of causative agents of gastrointestinal illnesses thus needs to be monitored regularly. The most problematic bacteria potentially found in tap water according to WHO are Vibrio cholerae, Salmonella typhi, Shigella spp., Campylobacter jejuni, E. coli, Yersinia enterolitica, Legionella spp., Aeromonas spp., Mycobacterium spp., Bacillus spp. and P. aeruginosa (WHO 2011; EEC 1998). Caution is also needed in case of rapid propagation of toxinproducing Cyanobacteria of the genera Microcystis, Planktothrix, Anabaena, Oscillatoria and Aphanizomenon (Szewzyk et al. 2000; Percival et al. 2014). However, the presence, diversity and ecological interactions of water- 
borne bacteria remain poorly investigated and understood. These gaps in knowledge are now primarily addressed using high-throughput sequencing methods (Callewaert et al. 2015). The number of bacteria reaches its lowest limits in water tanks after treatment procedures (e.g. chlorination), while in tap water the number of bacteria increases again due to the presence of biofilms in plumbing systems (Kormas et al. 2010). Thus, the numbers of $\mathrm{CFU}$ in groundwater can be up to $10^{6} \mathrm{CFU} /$ $\mathrm{mL}$, in well water up to $10^{3} \mathrm{CFU} / \mathrm{mL}$, in reservoir tanks after chlorination up to $10^{2} \mathrm{CFU} / \mathrm{mL}$ and in household tap water between $10^{2}$ and $10^{5} \mathrm{CFU} / \mathrm{mL}$ (Kormas et al. 2010; Callewaert et al. 2015). Their diversity depends greatly on environmental factors such as disinfectant, temperature, flow and building materials (Wang et al. 2014). Typical bacteria in ground and well water are Betaproteobacteria (Kormas et al. 2010). The same class is usually also dominant in cold water in the indoor plumbing system (Inkinen et al. 2016). In biofilms of the lower parts of the plumbing system (e.g. basement and first floor), in systems with regular water consumption and relatively high water flow, Alphaproteobacteria dominate over Betaproteobacteria (Inkinen et al. 2016). This is also true in copper pipes (Inkinen et al. 2016), while cross-linked polyethylene (PEX) pipes in combination with hot water appear to select for Betaproteobacteria, Gammaproteobacteria, Actinobacteria and Bacilli (Callewaert et al. 2015; Inkinen et al. 2016; Moat et al. 2016).

\section{Indoor biomes are shaped by selection driven by anthropogenic factors}

Microorganisms entering buildings via tap water become exposed to different physico-chemical factors, which shape the diversity of the communities in indoor habitats. Exposure to unfavourable life conditions (e.g. desiccation, high or low temperatures, variable $\mathrm{pH}$ ) leads to a constant selection of the best adapted species. A metagenomic study of indoor microorganisms reported enrichment of genes involved in overcoming iron limitation, oxidative damage and desiccation (Tringe et al. 2008). While high humidity makes some indoor habitats more prone to microbial growth, even the most humid parts of the household represent major challenges to microorganisms. Not only because water availability is often not constant (occasional desiccation triggers high levels of stress), but also due to other conditions. These include the often scarce sources of nutrients, which have to be derived from the environment or from the building materials (Gorny 2004), sometimes including unusual compounds such as surfactants found in cosmetic products (Hamada and Abe 2010) or from other microbes. Studies of microbial diversity of indoor environments have shown that indoors should not be seen as a homogenous environment. Instead, many different habitats can be recognised, some very specific, with profoundly different microbial communities, shaped by different selection pressures. Hostile conditions usually also result in a rather limited number of species found in each specific habitat. Showerheads, with their abundance of water, represent a challenge to microbes due to mechanical forces and water chlorination, two factors that presumably select for biofilm-forming species (Feazel et al. 2009) (Fig. 1). As will be discussed later, the drive towards the use of biodegradable materials, including the substitution of aggressive chemical detergents with more environmentally friendly alternatives, not only decreases the amount of antimicrobial compounds in the household, but in some cases even provides additional nutrients. This does not mean that antimicrobial substances do not come with their own set of potential problems. One of the infamous antibacterial compounds used and released in great quantities is triclosan (Levy 2001; Fang et al. 2010), which is used not only despite that fact that its benefits remain unproven (FDA 2019), but also despite the risks it poses - antimicrobials such as triclosan have for example been linked to the selection of bacteria with higher resistance to antibiotics (Westfall et al. 2019). Other factors that limit microbial diversity and abundance indoors are oxidative stress (oxidative chemicals, such as bleach or hydrogen peroxide, are found in many household cleaning agents), chemicals that change chaotropicity (Hallsworth et al. 2003) or hydrophobicity (Bhaganna et al. 2010), and provide unusual sources of nutrients, such as aromatic pollutants.

Microbial growth in indoor environments is difficult to overlook and at least bacterial abundance has been studied for decades, focusing particularly on the places most prone to contamination, such as kitchens and bathrooms (Ojima et al. 2002; Beumer and Kusumaningrum 2003). Compared to bacteria, the high abundance of fungi in anthropogenic habitats is less studied. Some recent studies have uncovered a surprising diversity including pathogenic species in hospitals (Garcia-Cruz et al. 2012). Opportunistic fungal pathogens are present also in residential buildings, where habitats with regular presence of liquid water (e.g. plumbing, sinks or drains) support active growth and accumulation of high biomass, while dry surfaces contain mostly species deposited from air and aerosols (Adams et al. 2013; Zalar et al. 2011). Polyextremotolerant oligotrophic fungi are particularly common in indoor wet cells (Zalar et al. 2011; Hamada and Abe 2010; Lian and de Hoog 2010).

\section{Indoor environments dominated by water-borne microorganisms}

\section{Kitchen surfaces}

Among places inside our homes, kitchens are most heavily colonised by microbes and are a place where people are 


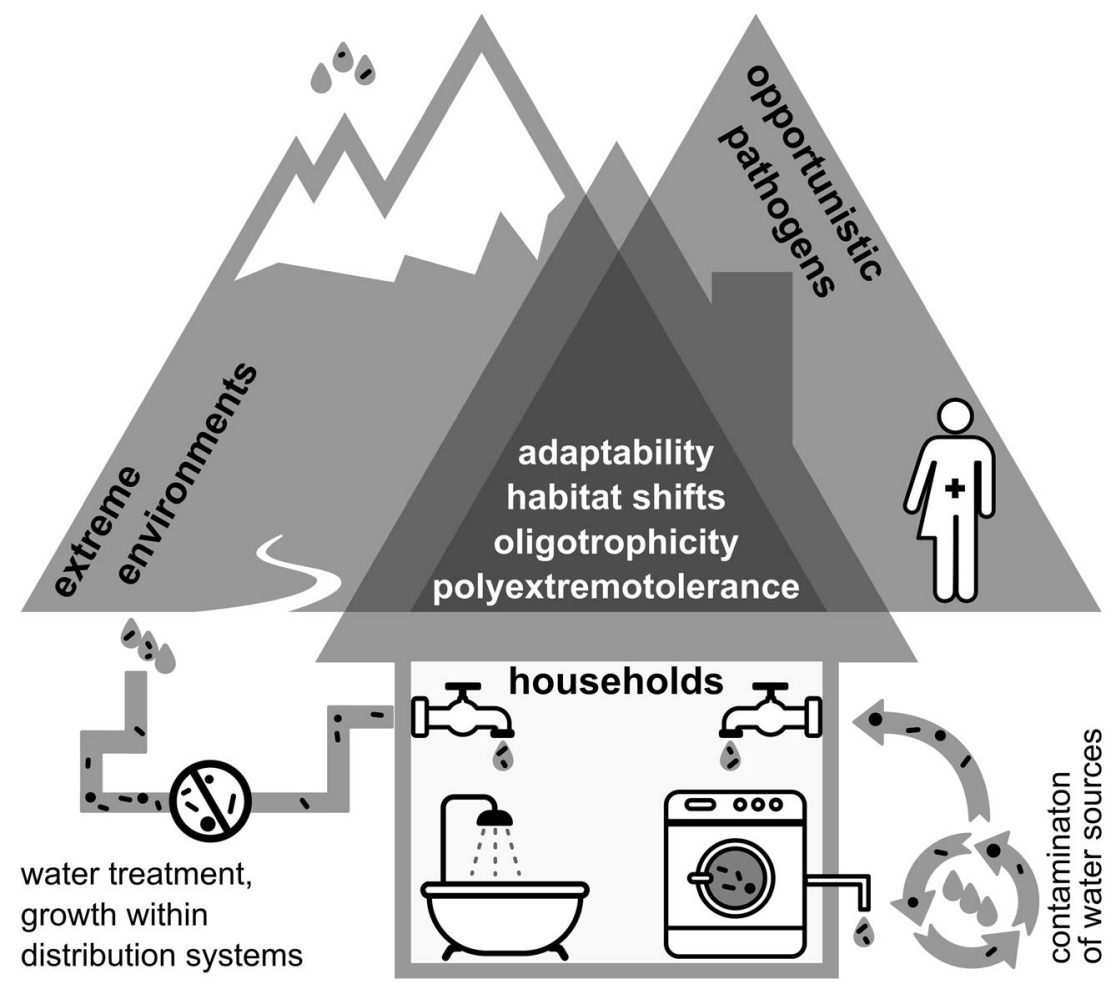

Fig. 1 Water-related microorganisms in the households. Biofilm formation, oligotrophicity, resistance to water treatment procedures, resistance to occasional desiccation and cleaning procedures are among traits promoting survival of water-related microbes indoors. Species surviving such conditions are characterised by great adaptability, stress tolerance and capability of habitat shifts. All of these are traits they share with some species found in extreme natural environments and also in opportunistic pathogens, for which the infection of the human body can be seen as just another habitat shift exposing them to a new and stressful environment. Tap water distribution systems provide opportunities for microbial growth of adapted microorganisms. After entering the household with water, different habitats support the formation of many, in some cases very specific communities, shaped by the conditions of each habitat (such as shower heads or household appliances). In some cases, the enriched microorganisms leave the household in large numbers (e.g. with wastewater), possibly contaminating water sources and re-entering the households at a later time typically exposed to the broadest diversity of microorganisms while indoors (Sinclair and Gerba 2011). Exposure to microbes comes from handling and preparing food and from contact with kitchen surfaces that harbour microorganisms derived from food, water, air and humans (Medrano-Felix et al. 2011). Although outdoor and indoor air and water are known sources of microbial contamination of kitchens, human skin was found to be the primary source of bacteria belonging to the families Propionibacteriaceae, Corynebacteriaceae, Staphylococcaceae and Streptococcaceae (Flores et al. 2011; Flores et al. 2012). Diversity of bacterial communities of typical household kitchens was studied in detail only recently and it revealed that moist surfaces in kitchens usually yield the highest number of microbes due to the presence of water essential for microbial propagation (Sinclair and Gerba 2011; Flores et al. 2012). Most abundant bacteria belong to the families Micrococcaceae, Flavobacteriaceae, Streptococcaceae and Moraxellaceae (Flores et al. 2012). These families contain bacterial genera able to survive on solid surfaces for a long time (Santo et al. 2010). Most diverse bacterial communities were found outside the stove exhaust fans and on the surface of the floor as a consequence of passive and active deposition of particulates and infrequent cleaning. On the other hand, the least diverse communities were observed on metallic surfaces (kitchen sinks, faucets, sink drains, sink basins) and were dominated by Gram-negative bacteria, known to produce stable biofilms (e.g. Sphingomonadaceae) (Kelley et al. 2004; Flores et al. 2012). Gram-positive Firmicutes, able to form spores, were more abundant on dry surfaces (e.g. floors, cabinets and microwaves) (Flores et al. 2012). While the majority of bacteria found on kitchen surfaces are harmless, some surfaces with a direct contact with raw food can harbour pathogenic bacteria (Berger et al. 2010). In developed countries, bacterial food-borne illnesses are mainly connected to different bacterial species Bacillus cereus, Campylobacter spp., Salmonella spp., C. perfringens, E. coli and Listeria monocytogenes (Mead et al. 1999; Bintsis 2017). Campylobacter species were mainly present on surfaces above counter tops, on upper cabinet handles and on the microwave panels. Contamination of these surfaces is thought to occur via hands of persons who handled raw poultry, 
known to be frequently contaminated with Campylobacter (Luber 2009; Flores et al. 2012).

Kitchen sponges are the most colonised object in kitchens, with the highest load of microbes. Their porous construction, constantly humid environment and contact with food enable successful colonisation and propagation of microbes (Alwakeel 2007). Bacteria E. coli, Enterobacter cloacae, Proteus spp., Klebsiella spp., Campylobacter spp. and Salmonella spp. usually originating from food ingredients are commonly present on kitchen sponges and later transferred to the surfaces made of steel or plastics (Rossi et al. 2013; Cardinale et al. 2017). Next-generation sequencing (NGS) also revealed the presence of water-borne bacteria Acinetobacter johnsonii, A. pittii, A. ursingii, Chryseobacterium hominis and Moraxella osloensis belonging to the Biosafety Level 2 along with known biofilm producers of the genera Pseudomonas, Sphingomonas and Rhizobium (Table 1) (Cardinale et al. 2017). Among fungi, genus Aspergillus is the most commonly encountered (Alwakeel 2007).

Fungal presence in household kitchens was for a long time connected only to indoor air and dust, or contaminated food. Recently, conducted studies suggested tap water as an important additional vector (Novak Babič et al. 2016b). Fungal presence and active growth were recently investigated on sills, drains, sinks and pipes (Adams et al. 2013; Zupančič et al. 2016) (Fig. 2). Ubiquitous genera of filamentous fungi like Aspergillus, Cladosporium and Penicillium were present mainly on surfaces exposed to outdoor air (e.g. sills next to windows) (Adams et al. 2013), while moist surfaces in regular contact with water harboured yeasts from the genera Apiotrichum, Candida, Cryptococcus, Cystobasidium, Issatchenkia, Malassezia, Meyerozyma, Naganishia, Hyphopichia, Pichia, Rhodotorula, Trichosporon, Wickerhamiella and Wickerhamomyces, and black yeasts Aureobasidium, Capronia, Cyphellophora, Cladophialophora, Exophiala, Fonsecaea, Knufia, Phialophora and Rhinocladiella (Table 1) (Zupančič et al. 2016; Wang et al. 2018), many of which were previously reported also from tap water (Zupančič et al. 2016; Novak Babič et al. 2016b). Filamentous fungi belonging to the genera Fusarium, Ochroconis and Phoma were also regularly encountered, especially in biofilms on drains and sinks (Adams et al. 2013; Zupančič et al. 2016). Species that should cause the most concern are human opportunistic fungi, able to cause diseases in immunocompromised people, particularly species secreting extracellular polysaccharides (EPS). These species can form mixed bacterial-fungal biofilms and can thus adhere more easily to human hands (e.g. species from genera Candida, Cryptococcus, Malassezia and Rhodotorula). Fungi spread by air or aerosols, such as representatives of the genera Aspergillus, Cladosporium, Fusarium and Penicillium, can pose a risk for people suffering from allergies or asthma. Some fungi can present problems if inoculated on the skin or subcutaneously by skin trauma, melanised black fungi being particularly problematic (de Hoog et al. 2014).

\section{Bathrooms}

Bacteria colonising bathroom surfaces have various routes of entry. The major ones are tap water, human skin and oral biota, and faecal contamination (in case of coliform bacteria) (Ankola et al. 2009). Water-related bacteria are colonising interiors of water pipes and shower hoses and belong mainly to Alphaproteobacteria followed by Actinobacteria (Moat et al. 2016). Pathogens of the genera Pseudomonas, Mycobacterium and Legionella are commonly encountered (Moat et al. 2016). These are dispersed through aerosols and are able to cause respiratory infections. Other infections are also possible, such as the $P$. aeruginosa keratitis due to the biofilm formation on contact lenses left in bathroom, reported by Eguchi et al. (2013).

After kitchen sponges, the object with the second highest microbial load indoors are toothbrushes. Similarly, these are made of a polymer with a large surface, which is constantly wet and repeatedly exposed to microbes present in the oral cavity and on the skin (Patcas et al. 2018). Bacteria Streptoccous mutans, $\beta$-haemolytic streptococci and yeast C. albicans are the most common residents of plastic bristles and causative agents of repeated infections (Ankola et al. 2009). Other skin- and faeces-related bacteria, such as those from the genera Citrobacter, Enterobacter, Escherichia, Klebsiella, Serratia, Enterococcus, Streptococcus and Staphylococcus spp. could be found on the floor, drains, sinks, toilet seats and counters across the bathrooms (Table 1) (Cole et al. 2003).

Similarly to bacteria, fungi colonising bathroom surfaces can also originate from tap water or skin. Water-borne fungi represent a diversity of species from the genera Aureobasidium, Cladosporium, Cryptococcus, Cyphellophora, Exophiala, Fusarium, Knufia, Leptosphaeria, Malassezia, Naganishia, Ochroconis, Phialophora, Rhinocladiella and Schizophylum (Table 1) (Wang et al. 2018; Novak Babič et al. 2017a, b; Moat et al. 2016). These genera can be isolated from taps, sinks and seals between ceramic bathroom tiles (Fig. 2) (Wang et al. 2018). Shower curtains, sinks and floors in contact with skin are additionally colonised with Candida and Rhodotorula (Hamada and Fujita 2000; Novak Babič et al. 2017b). Use of soaps and shampoos provides the scaffold for biofilm formation and greatly supports the growth of alkali-tolerant fungi degrading the ingredients of detergents (Hamada and Fujita 2000; Hamada and Abe 2010; Lian and de Hoog 2010). Constantly humid conditions also support the growth of airborne fungi of the genera Aspergillus, Cladosporium and Penicillium, which often colonise upper walls and ceilings 
Table 1 The most common bacterial and fungal species reported from different water-related indoor habitats

\begin{tabular}{|c|c|c|c|}
\hline Indoor habitat & Bacteria & Fungi & References \\
\hline Kitchens & $\begin{array}{l}\text { Acinetobacter johnsonii } \\
\text { Acinetobacter pittii } \\
\text { Acinetobacter ursingii } \\
\text { Bacillus cereus } \\
\text { Campylobacter } \text { spp. } \\
\text { Clostridium perfringens } \\
\text { Chryseobacterium hominis } \\
\text { Enterobacter cloacae } \\
\text { Escherichia coli } \\
\text { Klebsiella } \text { spp. } \\
\text { Listeria monocytogenes } \\
\text { Moraxella osloensis } \\
\text { Proteus spp. } \\
\text { Pseudomonas spp. } \\
\text { Rhizobium } \text { spp. } \\
\text { Salmonella } \text { spp. } \\
\text { Sphingomonas } \text { spp. }\end{array}$ & 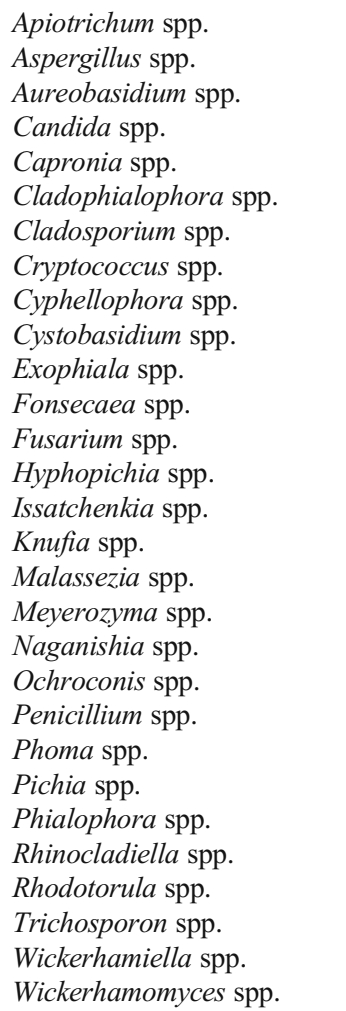 & $\begin{array}{l}\text { Adams et al. } 2013 \\
\text { Alwakeel } 2007 \\
\text { Bintsis } 2017 \\
\text { Cardinale et al. } 2017 \\
\text { Flores et al. } 2011 \\
\text { Flores et al. } 2012 \\
\text { Kelley et al. } 2004 \\
\text { Mead et al. } 1999 \\
\text { Novak Babič et al. 2016b } \\
\text { Rossi et al. } 2013 \\
\text { Wang et al. } 2018 \\
\text { Zupančič et al. } 2016\end{array}$ \\
\hline Dishwashers & $\begin{array}{l}\text { Acinetobacter baumannii } \\
\text { Bacillus cereus } \\
\text { Escherichia coli } \\
\text { Pseudomonas aeruginosa Stenotrophomonas } \\
\quad \text { maltophilia }\end{array}$ & $\begin{array}{l}\text { Candida parapsilosis } \\
\text { Exophiala dermatitidis } \\
\text { Exophiala phaeomuriformis } \\
\text { Fusarium spp. } \\
\text { Magnusiomyces capitatus } \\
\text { Meyerozyma guilliermondii } \\
\text { Pichia spp. } \\
\text { Rhodotorula mucilaginosa } \\
\text { Saccharomyces cerevisiae } \\
\text { Saprochaete clavata }\end{array}$ & $\begin{array}{l}\text { Döğen et al. 2013a, b } \\
\text { Gümral et al. } 2015 \\
\text { Zalar et al. } 2011 \\
\text { Zupančič et al. } 2016 \\
\text { Zupančič et al. } 2019\end{array}$ \\
\hline $\begin{array}{l}\text { Refrigerators and } \\
\text { freezers }\end{array}$ & $\begin{array}{l}\text { Arthrobacter spp. } \\
\text { Bacillus spp. } \\
\text { Carnobacterium spp. } \\
\text { Escherichia coli } \\
\text { Flavobacterium spp. } \\
\text { Lactobacillus spp. } \\
\text { Listeria } \text { spp. } \\
\text { Pantoea } \text { spp. } \\
\text { Pseudomonas spp. } \\
\text { Salmonella spp. } \\
\text { Sphingobacterium spp. } \\
\text { Staphylococcus spp. }\end{array}$ & $\begin{array}{l}\text { Acremonium spp. } \\
\text { Alternaria } \text { spp. } \\
\text { Aspergillus } \text { spp. } \\
\text { Botrytis cinerea } \\
\text { Candida } \text { spp. } \\
\text { Cladosporium } \text { spp. } \\
\text { Cyphellophora spp. } \\
\text { Exophiala } \text { spp. } \\
\text { Knufia } \text { spp. } \\
\text { Mucor racemosus } \\
\text { Ochroconis spp. } \\
\text { Penicillium italicum } \\
\text { Rhinocladiella } \text { spp. } \\
\text { Rhizopus oryzae } \\
\text { Scopulariopsis spp. }\end{array}$ & $\begin{array}{l}\text { Altunatmaz et al. } 2012 \\
\text { Buchholz et al. } 2011 \\
\text { Jeon et al. } 2013 \\
\text { Maktabi et al. } 2013 \\
\text { Wang et al. } 2018\end{array}$ \\
\hline Bathrooms & $\begin{array}{l}\text { Citrobacter spp. } \\
\text { Enterobacter spp. } \\
\text { Enterococcus spp. } \\
\text { Escherichia } \text { spp. } \\
\text { Klebsiella } \text { spp. } \\
\text { Legionella } \text { spp. } \\
\text { Mycobacterium spp. } \\
\text { Pseudomonas spp. }\end{array}$ & $\begin{array}{l}\text { Aspergillus spp. } \\
\text { Aureobasidium spp. } \\
\text { Candida spp. } \\
\text { Cladosporium spp. } \\
\text { Cryptococcus spp. } \\
\text { Cyphellophora spp. } \\
\text { Exophiala spp. } \\
\text { Fusarium spp. }\end{array}$ & $\begin{array}{l}\text { Ankola et al. } 2009 \\
\text { Cole et al. } 2003 \\
\text { Eguchi et al. } 2013 \\
\text { Hamada and Abe } 2010 \\
\text { Hamada and Fujita } 2000 \\
\text { Moat et al. } 2016 \\
\text { Novak Babič et al. 2017a, } \\
\text { b }\end{array}$ \\
\hline
\end{tabular}


Table 1 (continued)

\begin{tabular}{|c|c|c|c|}
\hline Indoor habitat & Bacteria & Fungi & References \\
\hline Washing machines & $\begin{array}{l}\text { Acinetobacter spp. } \\
\text { Bacillus spp. } \\
\text { Clostridium difficile } \\
\text { Corynebacterium spp. } \\
\text { Enhydrobacter spp. } \\
\text { Escherichia coli } \\
\text { Klebsiella pneumoniae } \\
\text { Klebsiella oxytoca } \\
\text { Micrococcus luteus } \\
\text { Pseudomonas spp. } \\
\text { Sphingomonas spp. } \\
\text { Staphylococcus aureus }\end{array}$ & $\begin{array}{l}\text { Knufia spp. } \\
\text { Leptosphaeria } \text { spp. } \\
\text { Malassezia } \text { spp. } \\
\text { Naganishia } \text { spp. } \\
\text { Ochroconis spp. } \\
\text { Penicillium spp. } \\
\text { Phialophora spp. } \\
\text { Rhinocladiella spp. } \\
\text { Rhodotorula } \text { spp. } \\
\text { Schizophylum spp. } \\
\text { Alternaria } \text { spp. } \\
\text { Aspergillus spp. } \\
\text { Candida albicans } \\
\text { Candida parapsilosis } \\
\text { Capronia } \text { spp. } \\
\text { Cladosporium spp. } \\
\text { Cryptococcus spp. } \\
\text { Cystobasidium slooffiae } \\
\text { Exophiala } \text { spp. } \\
\text { Fusarium oxysporum species complex } \\
\text { (FOSC) } \\
\text { Knufia } \text { spp. } \\
\text { Microsporum canis } \\
\text { Naganishia } \text { spp. } \\
\text { Ochroconis spp. } \\
\text { Penicillium spp. } \\
\text { Rhodotorula } \text { spp. } \\
\text { Trichophyton spp. } \\
\text { Trichosporon spp. }\end{array}$ & $\begin{array}{l}\text { Callewaert et al. } 2015 \\
\text { Gattlen et al. } 2010 \\
\text { Kubota et al. } 2012 \\
\text { Novak Babič et al. } 2015 \\
\text { Panagea et al. } 2005 \\
\text { Perry et al. } 2001 \\
\text { Rozman et al. } 2013 \\
\text { Schmithausen et al. } 2019 \\
\text { Stapleton et al. } 2013 \\
\text { Tanaka et al. } 2006 \\
\text { Wang et al. } 2018\end{array}$ \\
\hline Clothes dryers & $\begin{array}{l}\text { Bacillus spp. } \\
\text { Staphylococcus aureus } \\
\text { Streptococcus pyogenes }\end{array}$ & No data & $\begin{array}{l}\text { Brunton } 1995 \\
\text { Fijan and Šostar Turk } \\
\quad 2012\end{array}$ \\
\hline Saunas & $\begin{array}{l}\text { Bacillus spp. } \\
\text { Janthinobacterium } \mathrm{sp} . \\
\text { Pseudoxanthomonas taiwanensis } \\
\text { Stenotrophomonas sp. } \\
\text { Tepidomonas } \mathrm{sp} . \\
\text { Virgibacillus } \mathrm{sp} .\end{array}$ & $\begin{array}{l}\text { Candida spp. } \\
\text { Exophiala dermatitidis } \\
\text { Phialophora spp. } \\
\text { Rhinocladiella } \text { spp. }\end{array}$ & $\begin{array}{l}\text { Lee and Park } 2012 \\
\text { Novak Babič et al. } 2017 \mathrm{~b}\end{array}$ \\
\hline
\end{tabular}

(Hamada and Fujita 2000; Hamada and Abe 2010; Wang et al. 2018).

\section{Saunas}

Saunas usually harbour spore-forming bacteria, able to sustain high temperatures, pressure and humidity. The most commonly isolated bacterial species thus belonged to the genus Bacillus. Other bacteria were identified as Virgibacillus sp., Tepidomonas sp., Pseudoxanthomonas taiwanensis, Stenotrophomonas sp. and Janthinobacterium sp. (Lee and Park 2012). Similar trends can be observed for fungi, where more resilient thermotolerant and melanised species, such as Exophiala dermatitidis, Phialophora and Rhinocladiella, often dominate over other yeasts, such as Candida and dermatophytes (Table 1) (Novak Babič et al. 2017b).

\section{Household appliances enrich extremophilic microorganisms}

\section{Dishwashers}

In the last few decades, the presence of household dishwashers became widespread. This created a new habitat for harbouring and spreading potentially pathogenic microbes. Because of relatively high temperatures during washing cycles, regular addition of detergents and steel interior, it was believed that microbes can be completely removed and that any microbial presence inside the dishwasher was only transient and decidedly unproblematic. However, the first systematic study reported a consistent presence of certain species of fungi, including opportunistic pathogens, on rubber seals worldwide (Zalar et al. 2011). Dishwasher seals were 

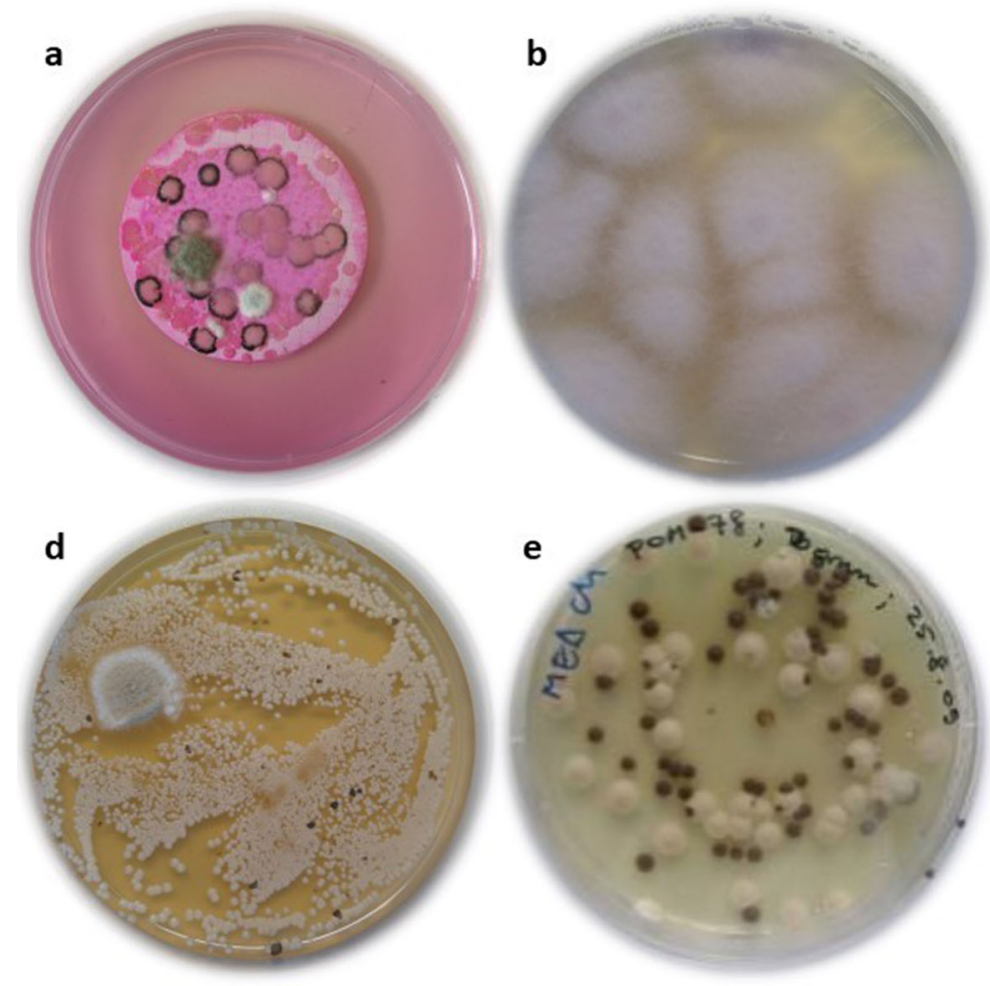

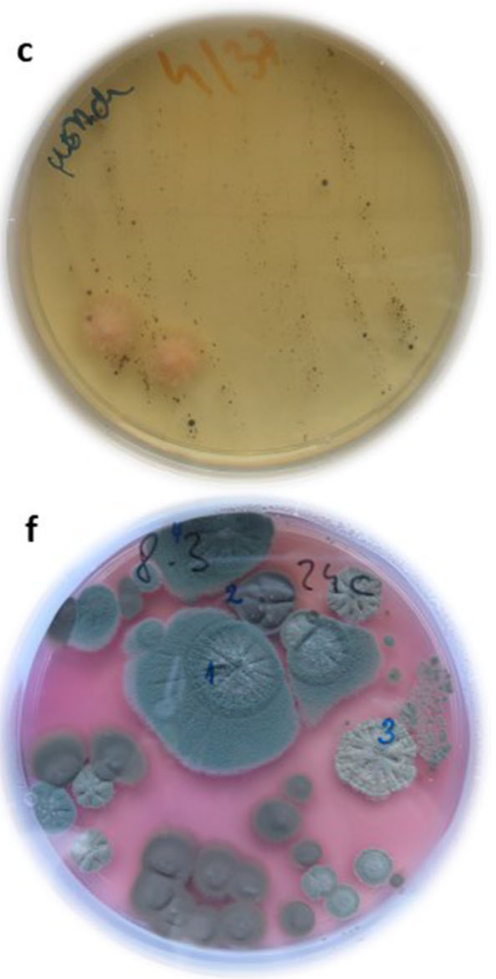

Fig. 2 Isolation plates with fungi from different indoor habitats linked to water. a Filter paper covered with colonies of Aureobasidium melanogenum and Aspergillus spp. isolated from 11 of drinking water on Dichloran Rose Bengal Agar with addition of chloramphenicol (DRBC+Ch). b Fusarium oxysporum species complex (FOSC) isolated on Malt Extract Agar with addition of chloramphenicol (MEA+Ch). Swab sample was taken from a detergent drawer in a washing machine. c Black yeasts and orange colonies of Bisifusarium dimerum isolated on Malt Extract Agar with addition of chloramphenicol (MEA+Ch). Swab sample was taken from a silicone in the bathroom. $\mathbf{d}$ Colonies of Candida parapsilosis sensu stricto and the black yeast Exophiala phaeomuriformis isolated on Malt Extract Agar with addition of chloramphenicol (MEA+ Ch). Swab sample was taken from moist kitchen desk. e Colonies of $C$. parapsilosis sensu stricto and the black yeast $E$. dermatitidis isolated on Malt Extract Agar with addition of chloramphenicol (MEA+Ch). Swab sample was taken from the rubber seal on the dishwasher's door. f Colonies of Aspergillus spp. and Cladosporium spp. isolated on Dichloran Rose Bengal Agar with addition of chloramphenicol $(\mathrm{DRBC}+\mathrm{Ch})$. Swab sample was taken from the rubber seal on the refrigerator's door colonised with different species regardless of their age, brand mark or use of detergents. Surprisingly, some fungi that are only rarely recovered from environment appeared to be main colonisers of dishwashers. Among them, opportunistic black yeasts $E$. dermatitidis and E. phaeomuriformis were found in the highest numbers, colonising between 30 and $50 \%$ of sampled dishwashers. Studies also revealed the presence of different Candida species, C. parapsilosis being predominant (Fig. 2 ), as well as the presence of otherwise ubiquitous Rhodotorula mucilaginosa and Fusarium spp. (Table 1) (Zalar et al. 2011; Döğen et al. 2013a, b; Gümral et al. 2015). In the following studies, results confirmed the existence of a core mycobiota (Zupančič et al. 2016) and identified tap water as the main source of contamination of dishwashers with these fungi (Novak Babič et al. 2016b). To a lesser extent, food also contributes to the fungal load in dishwashers, particularly with species Saccharomyces cerevisiae, Pichia spp. and opportunistic pathogens from the genera Magnusiomyces and Saprochaete (Zalar et al. 2011; Zupančič et al. 2016). Dishwashers not only represent a novel habitat, but also appear to act as a source of contamination. The presence of dishwashers has an important impact on the presence of opportunistic fungi on different kitchen surfaces. Kitchens without dishwashers are mainly colonised with species of the genera Candida, Meyerozyma, Pichia and Rhodotorula, while kitchens with dishwashers have significantly higher numbers of black yeasts from the genus Exophiala. It was confirmed that fungi from dishwashers can be present in hot aerosols, released immediately at the end of the washing cycle and in wastewater drained from the dishwashers (Zupančič et al. 2016).

The medical importance of opportunistic fungi colonising dishwashers is not well understood. So far, only one case report linked the infections with an opportunistic fungus and contaminated dishwashers. Menu et al. (2019) reported outbreaks caused by Saprochaete clavata in a haematology unit in Marseille, France. Genotyping later confirmed the same origin of the strains present in dishwashers used by the patients and their families and the clinical isolates of the fungus (Menu et al. 2019). 
The presence of bacteria in dishwashers was investigated later than the presence of fungi. A study conducted on 30 dishwasher rubber seals in Slovenia (Zupančič et al. 2019) revealed the presence of 74 species of bacteria. The majority were Gram-positive and sporogenic. Among them, bacteria from the phyla Firmicutes and Actinobacteria prevailed, with Bacillus cereus group being the most abundant. The study found several potentially pathogenic species, including Acinetobacter baumannii, P. aeruginosa and Stenotrophomonas maltophilia (Table 1). Strains of E. coli belonged to a non-pathogenic phylogenetic group A. The most tested bacteria showed high resistance to antibiotics such as cefotaxime, ceftazidime and ertapenem, while genes for virulence markers were detected only in $P$. aeruginosa strains. To evaluate water as the possible vector of contamination of dishwashers with bacteria, a metagenomic analysis of bacterial diversity in tap water was conducted. The study showed the dominance of Alphaproteobacteria and Betaproteobacteria in the water, while Actinobacteria and Firmicutes were present in much lower numbers. These results indicate that food and used dishes are the main source of bacteria found in dishwashers (Zupančič et al. 2019).

\section{Refrigerators and freezers}

Refrigerators and freezers operate at temperatures between 18 and $+12^{\circ} \mathrm{C}$. These temperatures slow down the metabolism of mesophilic microbes; however, they enable the growth of psychrotolerant and psychrophilic microorganisms. Additionally, differences in temperature inside appliances result in condensate formation and thus a relatively constant source of water, while parts made of plastic and rubber facilitate microbial attachment and biofilm formation. It was shown that the concentration of viable cells in refrigerators can be up to $10^{7} \mathrm{CFU} / \mathrm{cm}^{2}$ (Kennedy et al. 2005). Inner surfaces of refrigerators and freezers, especially door seals, are cleaned infrequently, adding to the microbial load on kitchen surfaces (Flores et al. 2012). Composition of bacterial microbiota inside refrigerators appeared to be unique for each household, depending on the frequency of cleaning and types of stored foods (Jeon et al. 2013). Nevertheless, cold interiors of refrigerators and freezers were mostly dominated by Grampositive, spore-forming representatives of Firmicutes (Flores et al. 2012), Actinobacteria and Bacteroidetes (Jeon et al. 2013). Genera Pseudomonas, Pantoea, Sphingobacterium, Flavobacterium, Carnobacterium, Lactobacillus, Arthrobacter, Bacillus and Staphylococcus, which dominated the interior of refrigerators (Table 1), were usually associated with stored food, especially untreated meat and vegetables (Jeon et al. 2013). There is a growing concern about foodborne pathogenic bacteria, such as Listeria spp., Salmonella spp., E. coli and Pseudomonas spp., which can be transmitted from food to refrigerator surfaces. Additionally problematic are too high temperatures inside refrigerators, which can promote growth of unwanted bacteria (Buchholz et al. 2011; Maktabi et al. 2013). Refrigerators and freezers are populated also by fungi. Currently, food and air appear to be the major source of fungi. Food-colonising fungi can pose a risk not only because of their potential virulence, but also due to their production of mycotoxins, some of which are detrimental for human health (NSF 2013). Penicillium italicum, Botrytis cinerea, Mucor racemosus and Rhizopus oryzae were isolated from the surfaces of refrigerators or from the air inside industrial freezers. Opportunistic pathogenic fungi belonging to the black yeasts Cyphellophora, Exophiala, Knufia, Rhinocladiella and Ochroconis were commonly isolated, in particular from rubber surfaces (Wang et al. 2018) and were additionally found, along with the genera Acremonium, Alternaria, Aspergillus, Candida, Cladosporium and Scopulariopsis on interior plastic parts and refrigerator ice and water dispensers (Table 1) (Fig. 2) (Altunatmaz et al. 2012).

\section{Washing machines}

Laundry appliances, especially washing machines, are among the most common appliances used in households. Microbial presence inside washing machines was investigated for decades, mainly because of the risk of cross-transmission of pathogens via laundry. Gram-negative bacteria in planktonic form can survive washing temperatures of up to $50^{\circ} \mathrm{C}$, while Gram-positive bacteria can survive even higher temperatures, up to $60^{\circ} \mathrm{C}$ (Munk et al. 2001). Thus, washing at low temperatures only reduces the number of live bacteria, both in water and on dirty clothes. Several studies reported colonisation of washing machines with bacteria from the genera Acinetobacter, Bacillus, Clostridium, Corynebacterium, Escherichia, Micrococcus, Pseudomonas and Staphylococcus (Table 1) (Perry et al. 2001; Panagea et al. 2005; Novak Babič et al. 2015). Their diversity varied depending on the water type and skin microbiota of the users (Callewaert et al. 2015). Particularly problematic is the presence of species Clostridium difficile, Staphylococcus aureus, Klebsiella pneumoniae and $P$. aeruginosa on laundry, since cross-contamination from laundry can occur, resulting in nosocomial infections (Rozman et al. 2013). Recently, a case report described a colonisation of newborns with the same genotype of Klebsiella oxytoca as was isolated from the detergent drawer and the rubber door seal of domestic washing machines (Schmithausen et al. 2019). Transfer and enrichment of some bacterial groups was shown also for cotton fabrics supporting the growth of the genera Enhydrobacter, Corynebacterium and Acinetobacter, while polyester fabrics in general favoured the growth of Micrococcus and Staphylococcus (Callewaert et al. 2015). Biofilm-forming genera such as Pseudomonas and Shingomonas frequently 
colonise plastic parts of the washing machine but are rarely transferred onto the laundry. However, their presence in washing machines causes persistent unpleasant odour due to bacterial degradation of detergents and other organic matter present on clothes and in the water and they are released into waste greywater, which exits the washing machines (Munk et al. 2001; Stapleton et al. 2013; Callewaert et al. 2015).

Although degradation of detergents, especially softeners, was reported also for various fungi, they are not involved in the development of unpleasant odour of clothes or washing machines (Stapleton et al. 2013; Novak Babič et al. 2015). Most fungi isolated from washing machines entered via tap water. They belong to the genera Alternaria, Aspergillus, Candida, Capronia, Cladosporium, Cryptococcus, Fusarium, Naganishia, Penicillium, Rhodotorula and Trichosporon (Table 1) (Fig. 2). The most contaminated sites were plastic parts (e.g. drawers for detergents) and rubber seals (Gattlen et al. 2010; Kubota et al. 2012; Stapleton et al. 2013; Novak Babič et al. 2015). Recently, it was confirmed that drawers for detergent can be populated by biofilmforming species, such as Fusarium oxysporum species complex, and emerging pathogen C. parapsilosis, as well as various black yeasts-Exophiala, Knufia and Ochroconis (Novak Babič et al. 2015, 2016a; Wang et al. 2018). However, the main concern in washing machines are the dermatophytic fungi and yeasts from the genera Microsporum, Trichophyton and Candida, due to their high infectivity rate and frequent cross-contamination of laundry (Tanaka et al. 2006).

\section{Clothes dryers}

There are few reports on microbial contaminations of clothes dryers (tumble dryers). So far, it has been reported that in spite of high temperatures (between 50 and $70^{\circ} \mathrm{C}$ ) and consequently significant reduction in the number of viable microorganisms on fabrics during drying, microbial cross-contamination of laundry can occur. Bacteria, such as Streptococcus pyogenes, Staphylococcus aureus and Bacillus spp., can survive the high temperatures in dryers, resulting in clinical outbreaks especially in hospital environments (Brunton 1995; Fijan and Šostar Turk 2012). At the same time, we are not aware of any published study investigating the microbial load of the clothes dryer interior. Frequent consumer reports of the presence of an unpleasant odour or even visible dark biofilms inside dryers suggest potential fungal contaminations.

\section{Man-made materials as a new factor in selection of indoor water-borne microorganisms}

Besides water availability, microbial colonisation is determined by the nutritional substances that can be derived from the building materials or environment (Gorny 2004), the presence of specific chemicals, such as surfactants from soap and shampoo (Hamada and Abe 2010) or from co-occurring microbial species. Understanding of the complex influence of materials on indoor microbiota will help us build indoor spaces and equip them in a way that will have predictable impacts on the diversity and abundance of microbes with the aim to minimise health hazards and promote human wellbeing (National Academies of Sciences).

In the role of different materials in promoting or preventing microbial disease, many studies have focused on objects acting as fomites, carriers of infectious agents and their possible antimicrobial properties. The longest reported periods of microbial persistence on surfaces are several months (Kramer et al. 2006) and while this is important in possible cross-contamination, the danger represented by the contaminated surface decreases with time. A quite different problem is microorganisms that actively grow indoors. The hot spots of these microorganisms are not so much the surfaces touched and contaminated by humans or animals, but much more the habitats with high availability of liquid water. The selection of materials in these habitats impeding or supporting microbial growth has exploded in the last decades - with some unpredicted consequences (Gostinčar et al. 2011). We now know that some biofilm-forming species including those pathogenic to humans can grow on polyethylene, polypropylene, rubber, stainless steel and other materials (Tsiaprazi-Stamou et al. 2019).

Building materials have always played a role in shaping indoor microbial communities. Even seemingly durable and inert materials such as stone are now known to support the growth of fungi, which can grow on them, form biofilms, penetrate into their structure and in the long term importantly contribute to their deterioration (Warscheid and Braams 2000). Fungal growth is possible on limestone and also on plaster, and several species have been shown to dissolve the $\mathrm{CaCO}_{3}$, among them strains of Penicillium chrysogenum and Aspergillus versicolor (Ponizovskaya et al. 2019). Newer, green building materials also present opportunities for growth of fungi, and as with conventional materials, with an external source of nutrients being an important factor contributing to growth (Mensah-Attipoe et al. 2015).

In the past, microorganisms in indoor environments could mostly choose between inorganic substrates such as stone or metal and much more easily degradable organic materials, often of plant origin. In the last few decades, however, another substrate has appeared and slowly started to dominate indoor spaces: synthetic polymers. These are also used in products designed to be in prolonged contact with water-water pipes, rubber seals, faucet aerators and many others. Produced in tens of millions of tons per year, different groups of polymers share one common trait: they are all highly resistant to biodegradation (Danso et al. 2019; SAPEA 2019). But just as some microbes can grow on glass, metals or silicon, others 
can grow on a range of organic surfaces such as plastic materials and other polymers (Isola et al. 2013). Additionally, plastic materials are completely inert. Some degraders of specific plastic polymers have already been found, particularly for polyurethane and polyethylene terephthalate (Danso et al. 2019; Narancic and O'Connor 2019), and while this degradation is in most cases slow and only partial, it may be enough to support slow growth of selected microorganisms. Furthermore, many of the frequently used plastics contain other chemicals in addition to the main polymer, which (among having other functions) act as fillers, stabilisers and plasticisers. These additives are often much smaller molecules, more amenable to microbial degradation (Danso et al. 2019). These substances can be seen as a new opportunity for the most adaptable and nutritionally versatile microbes, such as those exemplified by species that can use complex phenolic hydrocarbons as the sole source of carbon and energy (Prenafeta-Boldu et al. 2006).

With time, plastic deteriorates, with the resulting cracks and uneven surface providing a much larger surface area, which is also more difficult to clean. In nature as well as indoors, such plastics provide ample opportunities for microbial colonisation and this colonisation can contribute to further (bio) deterioration through physical, chemical and enzymatic means (Lucas et al. 2008). If a microorganism is to use the polymer (and not additives or external compounds) as a nutrient source, it then has to both depolymerise the large polymer molecules and also assimilate them (Shah et al. 2008). But even when microbes do not degrade plastics, plastics provide a very different surface for attachment than other materials. Bacterial biofilms on stainless steel were reported to be thinner and easier to remove than those found on polyethylene, which contained a higher proportion of viable bacteria - an important consideration when for example choosing the material of a kitchen sink, but also of tap water piping systems, where the formation of biofilms is linked with numerous problems impacting the safety of tap water. The difference was explained by differences in roughness, chemical composition and surface energy between both materials (Tsiaprazi-Stamou et al. 2019).

While microbial growth on plastics is generally seen as an aesthetic problem, it might have medical implications, too. Since the ability to degrade complex hydrocarbons, like stress tolerance, has been linked to fungal opportunistic pathogenicity, the fungi growing on plastic substrates may be selected for potentially more problematic species (Blasi et al. 2016; Gostinčar et al. 2018). Furthermore, in some circumstances, it can also be detrimental to the functionality of the plastic objects themselves. For example, some fungi known for their colonisation of synthetic polymers and production of aggressive metabolites are considered potentially problematic biocorrosive agents on the International Space Station and have caused problems on the orbital station Mir (reviewed in Novikova et al. 2006).

Another widely used material, providing a better surface for microbial attachment, is rubber, which is widely used to seal contacts between components of systems and appliances that need to be water-tight. In the investigation of materials used in tap water piping systems, rubber turned out to be by far the most problematic material in terms of biofilm formation (Szczotko et al. 2016). This matches well with the abundant fungal and bacterial colonisation of the rubber seals of dishwashers (Zalar et al. 2011; Zupančič et al. 2019).

Besides synthetic polymers, there are other compounds that have begun to be encountered by microbes indoors in the last decades and which have not been generally available in the past. Synthetic detergents used in soaps and shampoos are used widely and besides other sources of organic compounds (such as food in the kitchen, desquamated skin cells in the bathroom) provide a regular source of nutrients. Many of them are easily biodegradable and this is so by design. After the visible foaming pollution in streams and wastewater treatment plants in the 1940s and 1950 s, more degradable compounds were produced and in many regions the use of biodegradable detergents is now obligatory by law. Many surfactants degrade even before reaching the wastewater treatment plant (Cowan-Ellsberry et al. 2014; Merrettig-Bruns and Jelen 2009). Their remnants can be used by microorganisms as nutrient sources. Several of the fungi that are often isolated from bathrooms, Cladophialophora boppii, Exophiala spinifera, Exophiala salmonis, Phialophora europaea, Phoma herbarum and Scolecobasidium constrictum, are able to grow on a nonionic surfactant (polyoxyethylene (Danso et al. 2019) lauryl ether) used in shampoos as a nutrient source, while Aureobasidium sp. and Cladosporium cladosporioides can use sodium salts of fatty acids (Hamada and Abe 2010).

Commercial products containing detergents often also contain preservatives that hamper microbial growth (Smaoui and Hlima 2012). Infections connected with the use of non-medical liquid soaps in the medical settings have been ascribed to the packaging and dosage system rather than the soap itself, since in the soap any microbial contamination diminishes with time, for bacteria quicker than for fungi (Tyski et al. 2013). However, dilution of the soap, either by the user or by the producer, will also impair its antimicrobial properties and such soap has been shown to support the survival of bacteria such as K. oxytoca, Serratia liquefaciens, Shigella sonnei, Enterobacter cloacae, E. gergoviae and Serratia odorifera (Schaffner et al. 2018). Microorganisms can also grow in the soap water with which we wash them from our skin or objects. Escherichia coli and Enterococcus faecalis were shown to grow in the rinses of various soaps, except those 
containing triclosan, and chlorhexidine gluconate, respectively (Pérez-Garza et al. 2017).

\section{Clinical relevance of polyextremotolerant fungi found indoors}

Infection of mammal hosts is a rare ability in the fungal kingdom. Of the 140 orders distinguished based on current taxonomy, only $15 \%$ contain species that repeatedly show this infectious potential (Gostinčar et al. 2018). Fungi that successfully infect a human body have to overcome several obstacles, such as high temperature (Robert and Casadevall 2009), oxidative bursts of human phagocytes and severe iron limitation (Hamad 2008; Kumamoto 2008), and low water activity and low pH in case of skin penetration (Elias 2007). Only a handful of true fungal pathogens evolved virulence factors enabling them to infect healthy individuals. Although the list of opportunistic fungi is much longer, they cause infections only sporadically, primarily in immunocompromised hosts. It has been shown that traits promoting virulence in opportunists have likely evolved for enabling the survival of the fungus in the environment (Song et al. 2017), primarily in stressful conditions (Gostinčar et al. 2011). For example, in the known pathogen Cryptococcus neoformans, the mechanisms that enable its survival during infection probably evolved in response to stress in its primary ecological niche, bird manure (Brown et al. 2007). Adaptations to stress encountered outside the mammalian host (exaptations - -i.e., mechanisms that originally evolved for different purposes) can unintentionally facilitate the fungal establishment in the host (van Burik and Magee 2001; Casadevall 2007).

Although not the topic of this paragraph, some parallels can be found with the behaviour of bacterial opportunists, which has in many cases been studied for much longer than fungi. Perhaps one of the most obvious examples is Pseudomonas aeruginosa, a bacterium also tightly connected to habitats with good accessibility of water, such as faucets and drains. Similarly to fungal opportunists, it can tolerate various stresses (although not desiccation) and forms biofilms and causes a wide spectrum of diseases in immunocompromised patients (Bédard et al. 2016).

One of the most remarkable demonstrations of fungal stress tolerance is the growth of some fungi in extreme environments, in which by definition most microbial species cannot survive. Two modes of adaptation to extreme conditions were recognised. On the one hand, specialised extremophilic and extremotolerant species evolved to efficiently cope with one major specific stress factor and are thus limited in their capacity for habitat shifts. Polyextremotolerant species on the other hand tolerate many different types of stress and are often extremely adaptable (Gostinčar et al. 2010), prone to habitat shifts and colonisation of novel, including man-made indoor habitats, as exemplified by black yeasts $A$. melanogenum and
E. dermatitidis (Gostinčar et al. 2011; Zalar et al. 2011; Hamada and Abe 2010; Lian and de Hoog 2010). Based on the assumption that exaptations might be the link between polyextremotolerance and opportunistic pathogenicity, a kingdom-wide phylogenetic analysis showed a statistically significant co-occurrence of extremotolerance and opportunism at the level of fungal orders (Gostinčar et al. 2018).

The main traits that define fungal opportunism and colonisation of stressful indoor environments are thermotolerance in combination with osmotolerance/osmophily, and oligotrophism, together with siderophore production at 37 ${ }^{\circ} \mathrm{C}$, production of different hydrolytic enzymes, urease activity, use of different hydrocarbons as sole carbon source, tolerance to oxidative stress, melanisation and biofilm production (de Hoog et al. 2005; Gostinčar et al. 2018; Lavrin et al. 2020). While some of these traits are known for Candida spp., Fusarium oxysporum (FOSC) and $F$. solani complexes (FSSC), all of these are characteristic for the black yeast E. dermatitidis, dominant fungus in dishwashers around the world (Zalar et al. 2011; Lavrin et al. 2020), and A. melanogenum prevailing in tap water (Novak Babič et al. 2016b, 2017a).

Tolerance to oxidative stress is tightly linked to the lifestyle of polyextremotolerant fungi as shown for different polyextremotolerant yeasts, which contain numerous homologues of the three major enzymes involved in cellular oxidative stress responses (i.e. catalases, SODs, peroxiredoxins) (Gostinčar and Gunde-Cimerman 2018). Oxidative stress can be triggered both by abiotic stressors (high salinity, extreme temperatures, starvation, light, mechanical damage and other) (Gostinčar and Gunde-Cimerman 2018) and during infection. Oxidative burst is a crucial part of animal and plant immune responses (Hamad 2008; Kumamoto 2008), and fungal ability to tolerate oxidative bursts protects them against attacks by neutrophils (Leal et al. 2012).

Many polyextremotolerant fungi are additionally protected by melanisation of the cell walls. Melanin shields fungal cells by acting as a scavenger of reactive oxygen species, protecting them against different types of abiotic stress (Slepecky and Starmer 2009; Gostinčar et al. 2012; Kogej et al. 2007; Kejžar et al. 2013) and increases their resistance to lysis, phagocytosis and to clinically used antifungal agents (van Baarlen et al. 2007; Feng et al. 2001; Nosanchuk et al. 2015; Schnitzler et al. 1999; Lavrin et al. 2020).

Polyextremotolerant species use various mechanisms to overcome starvation, both in nature and in oligotrophic indoor water-related environments. This exaptation is advantageous also in the mammalian host, where nutrient limitation is an important defence mechanism. This is clearly demonstrated in the case of iron. During an infection in mammals, phagocytes restrict fungal growth by releasing mediators that sequester iron (Kumamoto 2008), while in extreme environments its availability is limited due to competing microbes and often 
by the generally low nutrient concentrations as well. Only fungi that can produce high-affinity iron-chelating compounds, such as siderophores, as exemplified by A. pullulans, can thrive in iron-limited conditions (Neilands 1993; Johnson 2008; Zajc et al. 2019).

A crucial step in the colonisation of any kind of surface is the adhesion of the microbial cells to the surface and formation of a biofilm - a consortium of microorganisms embedded in extracellular polymeric substances. Mature biofilms provide increased resilience to any attack by the host immune defences, to antimicrobial agents (Fanning and Mitchell 2012; Inci et al. 2012) and to different abiotic stressors present in extreme environments (Zajc et al. 2019; Zupančič et al. 2018).

Survival in animal hosts and extreme environments is also linked to the production of a wide repertoire of extracellular metabolites, i.e. the secretome. Urease activity is for example directly linked to animal pathogenesis in bacteria and fungi (Cox et al. 2000; Rutherford 2014). Increased pH due to urease activity reduces acidification and maturation of phagolysosomes, thus impairing pathogen killing and antigen presentation (Cox et al. 2000; Rutherford 2014). Proteases and lipases are well-known virulence factors that facilitate the spread of the pathogen through tissues or neutralise the components of the immune system (Singaravelu et al. 2014).

Some polyextremotolerant fungi are able to assimilate monoaromatic hydrocarbons as carbon sources, and these species are frequently encountered both in outdoor hydrocarbonpolluted environments and indoors in plastic-rich niches (Döğen et al. 2013a, b; Seyedmousavi et al. 2011; Zhao et al. 2010; Isola et al. 2013; Chandran and Das 2012). A physiological connection between hydrocarbon assimilation and neural infection was suggested for certain polyextremotolerant black yeasts (Prenafeta-Boldu et al. 2006; Lavrin et al. 2020).

While the above described traits are shared among many polyextremotolerant fungi, it appears that the decisive fungal virulence factor is thermotolerance, i.e. the ability to thrive at $37^{\circ} \mathrm{C}$ and above (Robert and Casadevall 2009; Chandran and Das 2012; Gostinčar et al. 2018). This generally rare ability among fungi might become more frequent in the future, due to increased urbanisation and increased occurrence of hightemperature domestic environments and thermal adaptations of fungi on a global scale (Gostinčar et al. 2011; Lavrin et al. 2020).

Thermotolerance being the crucial virulence factor is in line with the observation that opportunists and non-opportunists cannot be distinguished on the level of genomic signatures associated with pathogenicity (Gostinčar et al. 2018). The number of genes for known virulence factors, such as enzymes for secondary metabolite production, carbohydrateactive enzymes (CAZymes), small secreted proteins, peptidases and proteases (Monod et al. 2002; Fischbach and
Walsh 2006; van Baarlen et al. 2007; Feng et al. 2001; Nosanchuk et al. 2015; Schnitzler et al. 1999), nonribosomal peptide synthetases (NRPSs) involved in the synthesis of siderophores (Bushley and Turgeon 2010; Silva et al. 2011) and toxins (Walton 1996; Haese et al. 1993), all thought to be important for virulence and resistance to clinically used antifungal agents, was the same in opportunistic and other species (Langfelder et al. 2003; Schmaler-Ripcke et al. 2009). However, polyextremotolerant and opportunistic pathogenic fungi repeatedly share a common phylogenetic history, supporting the hypothesis that traits important for fungal pathogenicity are shaped also by selection pressures outside of the host, acquiring "accidental virulence" (Casadevall and Pirofski 2007). The overview of indoor opportunistic polyextremotolerant fungi showed that their distribution in the fungal tree of life is not even, corresponding to the repeated emergence of opportunistic pathogens in some groups, but not in others.

Many species of black fungi are now increasingly being recognised as medical problems (Silveira and Nucci 2001; Chowdhary et al. 2014; Lavrin et al. 2020). Greater numbers of susceptible hosts, improved diagnostics and recognition of water-related indoor microbiomes and changes of our lifestyle have all been proposed as reasons for this trend (Casadevall et al. 2011; Gostinčar et al. 2011, 2015). It appears that these fungi do not specialise for pathogenicity as such. Instead, the evolution of their invasive potential is uncoupled from their hosts and tightly linked to their polyextremotolerant ecology, the same ecology that is also behind their ability to inhabit and thrive in various indoor habitats and use the opportunities created by the changes in human lifestyle and indoor environments.

\section{Conclusions}

Good personal hygiene practices, proper hygiene of household surfaces and regular maintenance of household appliances can substantially lower the presence of indoor waterrelated microorganisms and can prevent most infections (Flores et al. 2012). Some microorganisms, however, are capable of surviving even rigorous sanitation treatments (Cooper 2010). This should be taken into consideration especially in households inhabited by immune-compromised people (Novak Babič et al. 2017a, b).

Microbiological analyses of water quality are typically limited to certain standard procedures and regulations, which are often outdated even before they are even generally accepted by international and national regulating bodies. Standard microbiological tests are - with few exceptions-designed to control the presence of the most medically relevant bacteria that represent health risks to humans and animals. However, a much less controlled problem is the emergence of new 
bacterial and fungal pathogens. These can be present in disinfected water, in long-lived biofilms inside the plumbing systems, inside household appliances and on other surfaces, particularly in kitchens and bathrooms. Here, microorganisms do not just persist, but may spread further within the household, survive wastewater treatments and return to the environment, potentially creating a microbial vicious circle.

Microorganisms are introduced into domestic appliances via water, air, dishware, food, hands and clothes. Of particular concern are polyextremotolerant microbes that can adapt to conditions inside household appliances (that are now also becoming common in less developed countries (ConsumerReports 2016; SURS 2020). Although appliances were designed to help consumers maintain cleanliness, biofilm formation inside their interiors cannot be prevented. These biofilms can be established on interior materials due to the constant presence of water, either entering the appliance from the tap water distribution system or condensing on the surface. Roughness of the materials, hydrophobicity and resistance of materials to microbial attack play important roles in biofilm establishment. Biofilms contain high concentrations of microbial cells, which can be sporadically released as aerosols into the air or as individual planktonic cells or clumps of cells into the water. These microbes could represent a hitherto largely overlooked danger for infection through inhalation of contaminated aerosols, trauma or contact with infected surfaces (Novak Babič et al. 2017a, b).

Two modes of adaptation can be recognised in microorganisms inhabiting humid indoor habitats (water, wet cells and household appliances). One is specialisation to a specific stress factor, a so-called monoextremotolerance, which is typically linked to limited capacity for habitat shifts. Such microorganisms are primarily found in refrigerators. Polyextremotolerant fungal species on the other hand tolerate many different types of stress and are often extremely adaptable and can populate household appliances such as dishwashers and washing machines in large numbers (Gostinčar et al. 2010). Such large adaptability and stresstolerance is thought to be linked to the great capacity of these fungi to colonise novel and generally inhospitable habitats, including the human body (Gostinčar et al. 2011). It is thought that adaptations to stress encountered outside the mammalian host evolved to promote the survival of the microbes in the environment, but can also serve as exaptations and thus (as a side effect) occasionally allow the establishment of some fungi in the host (van Burik and Magee 2001; Casadevall 2007). Many species of black extremophilic fungi are now being recognised as a medical issue (Silveira and Nucci 2001; Chowdhary et al. 2014). These black yeasts did not specialise for pathogenicity as such, but their invasive potential is tightly linked to their polyextremotolerant ecology and most likely uncoupled from their host-microbe relationship.
The present studies show that water is an important source of exposure to environmental microorganisms in domestic environments and that the selection of water-borne microorganisms during water treatment and upon entering the generally inhospitable indoor environment favours species with a higher virulence potential. While the number of studies supporting this observation is steadily increasing, more epidemiological and experimental approaches are needed to further elucidate the role of the domestic water microbiome in human health. With an ever-growing fraction of the world population living in megacities and spending a majority of their lives indoors, understanding the role of the complex household microbiome - beyond the few primary pathogens - is becoming increasingly urgent.

Acknowledgements We acknowledge the financial support from the Slovenian Research Agency to the Infrastructural Centre Mycosmo (MRIC UL) and to the programmes P1-0198 and P1-0170.

Author contribution NGC led the study. MNB, CG and NGC wrote the manuscript. All authors read and approved the manuscript.

Funding information The work of Dr. Monika Novak Babič and Dr. Cene Gostinčar was supported by Slovenian Research Agency (ARRS), under the programme number P1-0198.

\section{Compliance with ethical standards}

Conflict of interest The authors declare that they have no conflict of interest.

Ethics approval The present work did not include any animal or human samples or patient data.

Consent to participate and consent for publication All authors and institutions where the work was carried out have approved the content and authorship of the manuscript.

Open Access This article is licensed under a Creative Commons Attribution 4.0 International License, which permits use, sharing, adaptation, distribution and reproduction in any medium or format, as long as you give appropriate credit to the original author(s) and the source, provide a link to the Creative Commons licence, and indicate if changes were made. The images or other third party material in this article are included in the article's Creative Commons licence, unless indicated otherwise in a credit line to the material. If material is not included in the article's Creative Commons licence and your intended use is not permitted by statutory regulation or exceeds the permitted use, you will need to obtain permission directly from the copyright holder. To view a copy of this licence, visit http://creativecommons.org/licenses/by/4.0/.

\section{References}

Adams RI, Miletto M, Taylor JW, Bruns TD (2013) The diversity and distribution of fungi on residential surfaces. PLoS ONE 8(11): e78866. https://doi.org/10.1371/journal.pone.0078866 
Altunatmaz SS, Issa G, Aydin A (2012) Detection of airborne psychrotrophic bacteria and fungi in food storage refrigerators. Braz J Microbiol 43(4):1436-1443. https://doi.org/10.1590/S1517838220120004000027

Alwakeel SS (2007) Bacterial and Aspergillus spp. contamination of domestic kitchens in Riyadh, Saudi Arabia. Saudi J Biol Sci 14:1-6

Ankola AV, Hebbal M, Eshwar S (2009) How clean is the toothbrush that cleans your tooth? Int J Dent Hyg 7:237-240

Beadle IR, Verran J (1999) The survival and growth of an environmental Klebsiella isolate in detergent solutions. J Appl Microbiol 87:764 769. https://doi.org/10.1046/j.1365-2672.1999.00923.x

Bédard E, Prévost M, Déziel E (2016) Pseudomonas aeruginosa in premise plumbing of large buildings. Microbiol Open 5(6):937-956. https://doi.org/10.1002/mbo3.391

Beguin H, Nolard N (1996) Prevalence of fungi in carpeted floor environment: analysis of dust samples from living-rooms, bedrooms, offices and school classrooms. Aerobiologia 12:113-120. https:// doi.org/10.1007/bf02446603

Berger CN, Sodha SV, Shaw RK, Griffin PM, Pink D, Hand P, Frankel G (2010) Fresh fruit and vegetables as vehicles for the transmission of human pathogens. Environ Microbiol 12:2385-2397. https://doi. org/10.1111/j.1462-2920.2010.02297.x

Beumer RR, Kusumaningrum H (2003) Kitchen hygiene in daily life. Int Biodeterior Biodegradation 51:299-302

Bhaganna P, Volkers RJ, Bell AN, Kluge K, Timson DJ, McGrath JW, Ruijssenaars HJ, Hallsworth JE (2010) Hydrophobic substances induce water stress in microbial cells. Microb Biotechnol 3(6):701716. https://doi.org/10.1111/j.1751-7915.2010.00203.x

Bintsis T (2017) Foodborne pathogens. AIMS Microbiol 3(3):529-563. https://doi.org/10.3934/microbiol.2017.3.529

Blasi B, Poyntner C, Rudavsky T, Prenafeta-Boldú FX, Hoog S, Tafer H, Sterflinger K (2016) Pathogenic yet environmentally friendly? Black fungal candidates for bioremediation of pollutants. Geomicrobiol J 33(3-4):308-317. https://doi.org/10.1080/ 01490451.2015 .1052118

Brown SM, Campbell LT, Lodge JK (2007) Cryptococcus neoformans, a fungus under stress. Curr Opin Microbiol 10(4):320-325. https:// doi.org/10.1016/j.mib.2007.05.014

Brunton WA (1995) Infection and hospital laundry. Lancet 345:15741575

Buchholz U, Bernard H, Werber D, Bohmer MM, Remschmidt C, Wilking H, Delere Y, van der Heiden M, Adlhoch C, Dreesman J (2011) German outbreak of Escherichia coli O104: H4 associated with sprouts. New Engl J Med 365:1763-1770

Bushley KE, Turgeon BG (2010) Phylogenomics reveals subfamilies of fungal nonribosomal peptide synthetases and their evolutionary relationships. BMC Evol Biol 10:26. https://doi.org/10.1186/14712148-10-26

Byrd-Bredbenner C, Berning J, Martin-Biggers J, Quick V (2013) Food safety in home kitchens: a synthesis of the literature. Int $\mathrm{J}$ Environ Res Public Health 10:4060-4085

Callewaert C, Van Nevel S, Kerckhof FM, Granitsiotis MS, Boon N (2015) Bacterial exchange in household washing machines. Front Microbiol 6:1381. https://doi.org/10.3389/fmicb.2015.01381

Cardinale M, Kaiser D, Lueders T, Schnell S, Egert M (2017) Microbiome analysis and confocal microscopy of used kitchen sponges reveal massive colonization by Acinetobacter, Moraxella and Chryseobacterium species. Sci Rep 7(1):5791. https://doi.org/ 10.1038/s41598-017-06055-9

Casadevall A (2007) Determinants of virulence in the pathogenic fungi. Fungal Biol Rev 21:130-132

Casadevall A, Pirofski LA (2007) Accidental virulence, cryptic pathogenesis, Martians, lost hosts, and the pathogenicity of environmental microbes. Eukaryot Cell 6:2169-2174
Casadevall A, Fang FC, Pirofski LA (2011) Microbial virulence as an emergent property: consequences and opportunities. PLoS Pathog 7: e1002136

Chandran P, Das N (2012) Role of plasmid in diesel oil degradation by yeast species isolated from petroleum hydrocarbon-contaminated soil. Environ Technol 33:645-652

Chowdhary A, Perfect J, de Hoog GS (2014) Black molds and melanized yeasts pathogenic to humans. Cold Spring Harb Perspect Med 5(8): a019570. https://doi.org/10.1101/cshperspect.a019570

Cole EC, Addison RM, Rubino JR, Leese KE, Dulaney PD, Newell MS, Wilkins J, Gaber DJ, Wineinger T, Criger DA (2003) Investigation of antibiotic and antibacterial agent cross-resistance in target bacteria from homes of antibacterial product users and nonusers. J Appl Microbiol 95:664-676. https://doi.org/10.1046/j.1365-2672.2003. 02022.x

ConsumerReports (2016) The best matching washers and dryers. ConsumerReports, 1 p. http://www.consumerreports.org/cro/2013/ 06/the-best-matching-washers-and-dryers/index.htm (March, 2020)

Cooper I (2010) Microbial biofilms: case reviews of bacterial and fungal pathogens persisting on biomaterials and environmental substrata. In: Mendez-Vilas A (ed) Current research, technology and education topics in applied microbiology and microbial biotechnology, vol 12. Spain, Formatex Research Centre, Badajoz, pp 807-817

Cowan-Ellsberry C, Belanger S, Dorn P, Dyer S, McAvoy D, Sanderson H, Versteeg D, Ferrer D, Stanton K (2014) Environmental safety of the use of major surfactant classes in North America. Crit Rev Environ Sci Technol 44:1893-1993

Cox GM, Mukherjee J, Cole GT, Casadevall A, Perfect JR (2000) Urease as a virulence factor in experimental cryptococcosis. Infect Immun 68(2):443-448. https://doi.org/10.1128/iai.68.2.443-448.2000

Dannemiller KC, Gent JF, Leaderer BP, Peccia J (2016) Influence of housing characteristics on bacterial and fungal communities in homes of asthmatic children. Indoor Air 26:179-192

Danso D, Chow J, Streit WR (2019) Plastics: environmental and biotechnological perspectives on microbial degradation. Appl Environ Microbiol 85(19):e01095-e01019. https://doi.org/10.1128/AEM. 01095-19

de Hoog GS, Zalar P, van den Ende AHG, Gunde-Cimerman N (2005) Relation of halotolerance to human pathogenicity in the fungal tree of life: an overview of ecology and evolution under stress. In: Gunde-Cimerman N, Oren A, Plemenitaš A (eds) Adaptations to life at high salt concentrations in Archaea, Bacteria, and Eukarya. Springer, Dordrecht, pp 373-395

de Hoog GS, Guarro J, Gené J, Figueras MJ (2014) Atlas of Clinical Fungi, electronic version 4.0. Centraalbureau voor Schimmelcultures, Utrecht: http://www.clinicalfungi.org/ (November 2019)

Defra (2011) A review of fungi in drinking water and the implications for human health. Department for Environment, Food and Rural Affairs, Paris

Döğen A, Kaplan E, Ilkit M, de Hoog GS (2013a) Massive contamination of Exophiala dermatitidis and E. phaeomuriformis in railway stations in subtropical Turkey. Mycopathol 175:381-386

Döğen A, Kaplan E, Oksüz Z, Serin MS, Ilkit M, de Hoog GS (2013b) Dishwashers are a major source of human opportunistic yeast-like fungi in indoor environments in Mersin, Turkey. Med Mycol 5:493498

Doggett MS (2000) Characterisation of fungal biofilms within a municipal water distribution system. Appl Environ Microbiol 66(3):1249 1251

Dunn RR, Fierer N, Henley JB, Leff JW, Menninger HL (2013) Home life: factors structuring the bacterial diversity found within and between homes. PLoS ONE 8(5):e64133. https://doi.org/10.1371/ journal.pone. 0064133

EEC (1998) Council directive 98/83/EC on the quality of water intended for human consumption. Off J Eur Communities L330:32-54 
Eguchi H, Miyamoto T, Kuwahara T, Mitamura S, Mitamura Y (2013) Infectious conjunctivitis caused by Pseudomonas aeruginosa isolated from a bathroom. BMC Res Notes 6:245. https://doi.org/10. 1186/1756-0500-6-245

Elias PM (2007) The skin barrier as an innate immune element. Semin Immunopathol 29:3-14

Fang JL, Stingley RL, Beland FA, Harrouk W, Lumpkins DL, Howard P (2010) Occurrence, efficacy, metabolism, and toxicity of triclosan. J Environ Sci Health C Environ Carcinog Ecotoxicol Rev 28(3):147171. https://doi.org/10.1080/10590501.2010.504978

Fanning S, Mitchell AP (2012) Fungal Biofilms. PLoS Path 8:e1002585

FDA (2019) Safety and effectiveness of consumer antiseptic rubs; topical antimicrobial drug products for over-the-counter human use. Federal Register 84 FR 14847:14847-14864

Feazel LM, Baumgartner LK, Peterson KL, Frank DN, Harris JK, Pace NR (2009) Opportunistic pathogens enriched in showerhead biofilms. Proc Natl Acad Sci U S A 106(38):16393-16399. https:// doi.org/10.1073/pnas.0908446106

Feng B, Wang X, Hauser M, Kaufmann S, Jentsch S, Haase G, Becker JM, Szaniszlo PJ (2001) Molecular cloning and characterization of WdPKS1, a gene involved in dihydroxynaphthalene melanin biosynthesis and virulence in Wangiella (Exophiala) dermatitidis. Infect Immun 69(3):1781-1794. https://doi.org/10.1128/IAI.69.3. 1781-1794.2001

Fernandes S, Chaves Simões L, Lima N, Simões M (2019) Adhesion of filamentous fungi isolated from drinking water under different process conditions. Water Res 164:1149-1151. https://doi.org/10.1016/ j.watres.2019.114951

Fijan S, Šostar Turk S (2012) Hospital textiles, are they a possible vehicle for healthcare associated infections? Int J Environ Res Public Health 9:3330-3343

Fischbach MA, Walsh CT (2006) Assembly-line enzymology for polyketide and nonribosomal peptide antibiotics: logic, machinery, and mechanisms. Chem Rev 106:3468-3496

Flores GE, Bates ST, Knights D, Lauber CL, Stombaugh J, Knight R, Fierer N (2011) Microbial biogeography of public restroom surfaces. PLoS One 6(11):e28132. https://doi.org/10.1371/journal. pone. 0028132

Flores GE, Bates ST, Caporaso JG, Lauber CL, Leff JW, Knight R, Fierer N (2012) Diversity, distribution and sources of bacteria in residential kitchens. Environ Microbiol 15(2):588-596. https://doi.org/10. 1111/1462-2920.12036

Fouquier J, Schwartz T, Kelley ST (2016) Rapid assemblage of diverse environmental fungal communities on public restroom floors. Indoor Air 26:869-879. https://doi.org/10.1111/ina.12279

Garcia-Cruz CP, Aguilar MJN, Arroyo-Helguera OE (2012) Fungal and bacterial contamination on indoor surfaces of a hospital in Mexico. Jundishapur J Microbiol 5:460-464

Gattlen J, Amberg C, Zinn M, Mauclaire L (2010) Biofilms isolated from washing machines from three continents and their tolerance to a standard detergent. Biofouling 26:873-882

Gorny RL (2004) Filamentous microorganisms and their fragments in indoor air - a review. Ann Agric Environ Med 11:185-197

Gostinčar C, Gunde-Cimerman N (2018) Overview of oxidative stress response genes in selected halophilic fungi. Genes (Basel) 9(3):143. https://doi.org/10.3390/genes9030143

Gostinčar C, Grube M, De Hoog S, Zalar P, Gunde-Cimerman N (2010) Extremotolerance in fungi: evolution on the edge. FEMS Microbiol Ecol 71:2-11. https://doi.org/10.1111/j.1574-6941.2009.00794.x

Gostinčar C, Grube M, Gunde-Cimerman N (2011) Evolution of fungal pathogens in domestic environments? Fungal Biol 115:1008-1018

Gostinčar C, Muggia L, Grube M (2012) Polyextremotolerant black fungi: oligotrophism, adaptive potential, and a link to lichen symbioses. Front Microbiol 3:390. https://doi.org/10.3389/fmicb.2012.00390

Gostinčar C, Gunde-Cimerman N, Grube M (2015) Polyextremotolerance as the fungal answer to changing environments. In: Bakermans C (ed) Microbial evolution under extreme conditions. Life in extreme environments, vol 2. de Gruyter, Berlin, pp 185-208. https://doi.org/10.1515/9783110340716.185

Gostinčar C, Zajc J, Lenassi M, Plemenitaš A, de Hoog S, Al-Hatmi AMS, Gunde-Cimerman N (2018) Fungi between extremotolerance and opportunistic pathogenicity on humans. Fungal Divers 93:195213

Gümral R, Özhak-Baysan B, Tümgör A, Saraçlı MA, Yildiran ȘT, Ilkit M, Zupančič J, Novak Babič M, Gunde-Cimerman N, Zalar P, de Hoog GS (2015) Dishwashers provide a selective extreme environment for human-opportunistic yeast-like fungi. Fungal Divers 76:19

Gümral, R., Ozhak-Baysan, B., Tümgör, A., Ali Saraçli, M., Yıldıran, S.T., Ilkit, M., Zupančič, J., Novak Babič, M., Gunde-Cimerman, N., Zalar, P., de Hoog, G.S. Dishwashers provide a selective extreme environment for human-opportunistic yeast-like fungi. Fungal Diversity 76, 1-9 (2016). https://doi.org/10.1007/s13225015-0327-8

Haese A, Schubert M, Herrmann M, Zocher R (1993) Molecular characterization of the enniatin synthetase gene encoding a multifunctional enzyme catalyzing N-Methyldepsipeptide formation in Fusarium scirpi. Mol Microbiol 7:905-914

Hallsworth JE, Heim S, Timmis KN (2003) Chaotropic solutes cause water stress in Pseudomonas putida. Environ Microbiol 5:1270 1280

Hamad M (2008) Antifungal immunotherapy and immunomodulation: a double-hitter approach to deal with invasive fungal infections. Scand J Immunol 67(6):533-543. https://doi.org/10.1111/j.13653083.2008.02101.x

Hamada N, Abe N (2010) Growth characteristics of four fungal species in bathrooms. Biocontrol Sci 15:111-115

Hamada N, Fujita T (2000) Growth rate of fungi in bathrooms - experimental survey. Mycoscience 41:297-301

Hanson B, Zhou Y, Bautista EJ, Urch B, Speck M, Silverman F, Muilenberg M, Phipatanakul W, Weinstock G, Sodergren E, Gold DR, Sordillo JE (2016) Characterization of the bacterial and fungal microbiome in indoor dust and outdoor air samples: a pilot study. Environ Sci Process Impacts 18:713-724. https://doi.org/10.1039/ c5em00639b

Inci M, Atalay MA, Koc AN, Yula E, Evirgen O, Durmaz S, Demir G (2012) Investigating virulence factors of clinical Candida isolates in relation to atmospheric conditions and genotype. Turk J Med Sci 42: 1476-1483

Inkinen J, Jayaprakash B, Santo Domingo JW, Keinänen-Toivola MM, Ryu H, Pitkänen T (2016) Diversity of ribosomal 16S DNA- and RNA-based bacterial community in an office building drinking water system. J Appl Microbiol 120(6):1723-1738. https://doi.org/10. 1111/jam. 13144

Isola D, Selbmann L, de Hoog GS, Fenice M, Onofri S, Prenafeta-Boldu FX, Zucconi L (2013) Isolation and screening of black fungi as degraders of volatile aromatic hydrocarbons. Mycopathologia 175: 369-379

Jayaprakash B, Adams RI, Kirjavainen P, Karvonen A, Vepsäläinen A, Valkonen M, Järvi K, Sulyok M, Pekkanen J, Hyvärinen A, Täubel M (2017) Indoor microbiota in severely moisture damaged homes and the impact of interventions. Microbiome 5(1):138. https://doi. org/10.1186/s40168-017-0356-5

Jeon Y-S, Chun J, Kim B-S (2013) Identification of household bacterial community and analysis of species shared with human microbiome. Curr Microbiol 67:557-563

Johnson L (2008) Iron and siderophores in fungal-host interactions. Mycol Res 112:170-183

Kejžar A, Gobec S, Plemenitaš A, Lenassi M (2013) Melanin is crucial for growth of the black yeast Hortaea werneckii in its natural hypersaline environment. Fungal Biol 117:368-379 
Kelley S, Gilbert J (2013) Studying the microbiology of the indoor environment. Genome Biol 14:202

Kelley ST, Theisen U, Angenent LT, St Amand A, Pace NR (2004) Molecular analysis of shower curtain biofilm microbes. Appl Environ Microbiol 70(7):4187-4192. https://doi.org/10.1128/ AEM.70.7.4187-4192.2004

Kennedy J, Jackson V, Blair IS, McDowell DA, Cowan C, Bolton DJ (2005) Food safety knowledge of consumers and the microbial and temperature status of their refrigerators. J Food Prot 68:1421-1430

Kogej T, Stein M, Volkmann M, Gorbushina AA, Galinski EA, GundeCimerman N (2007) Osmotic adaptation of the halophilic fungus Hortaea werneckii: role of osmolytes and melanization. Microbiology 153:4261-4273

Kormas KA, Neofitou C, Pachiadaki M, Koufostathi E (2010) Changes of the bacterial assemblages throughout an urban drinking water distribution system. Environ Monit Assess 165(1-4):27-38. https:// doi.org/10.1007/s10661-009-0924-7

Kramer A, Schwebke I, Kampf G (2006) How long do nosocomial pathogens persist on inanimate surfaces? A systematic review. BMC Infect Dis 6:130

Kubota H, Mitani A, Niwano Y, Takeuchi K, Tanaka A, Yamaguchi N, Kawamura Y, Hitomi J (2012) Moraxella species are primarily responsible for generating malodor in laundry. Appl Environ Microbiol 78(9):3317-3324. https://doi.org/10.1128/AEM.0781611

Kumamoto CA (2008) Niche-specific gene expression during C. albicans infection. Curr Opin Microbiol 11(4):325-330. https://doi.org/10. 1016/j.mib.2008.05.008

Langfelder K, Streibel M, Jahn B, Haase G, Brakhage AA (2003) Biosynthesis of fungal melanins and their importance for human pathogenic fungi. Fungal Genet Biol 38(2):143-158

Larsen N, Vogensen FK, van den Berg FW, Nielsen DS, Andreasen AS, Pedersen BK, Al-Soud WA, Sørensen SJ, Hansen LH, Jakobsen M (2010) Gut microbiota in human adults with type 2 diabetes differs from non-diabetic adults. PLoS One 5(2):e9085. https://doi.org/10. 1371/journal.pone.0009085

Lavrin T, Konte T, Kostanjšek R, Sitar S, Sepčić K, Prpar Mihevc S, Žagar E, Župunski V, Lenassi M, Rogelj B, Gunde-Cimerman N (2020) The neurotropic black yeast Exophiala dermatitidis induces neurocytotoxicity in neuroblastoma cells and progressive cell death. Cells 9(4):963. https://doi.org/10.3390/cells9040963

Leal SM Jr, Vareechon C, Cowden S, Cobb BA, Latgé JP, Momany M, Pearlman E (2012) Fungal antioxidant pathways promote survival against neutrophils during infection. J Clin Invest 122(7):24822498. https://doi.org/10.1172/JCI63239

Lee YJ, Park HD (2012) Characterization of bacterial community contaminating floor of a hot and dry sauna. J Bacteriol Virol 42(4):313320. https://doi.org/10.4167/jbv.2012.42.4.313

Levy SB (2001) Antibacterial household products: cause for concern. Emerg Infect Dis 7:512-515

Lian X, de Hoog GS (2010) Indoor wet cells harbour melanized agents of cutaneous infection. Med Mycol 48:622-628

Luber P (2009) Cross-contamination versus undercooking of poultry meat or eggs - which risks need to be managed first? Int J Food Microbiol 134:21-28

Lucas N, Bienaime C, Belloy C, Queneudec M, Silvestre F, NavaSaucedo J-E (2008) Polymer biodegradation: mechanisms and estimation techniques - a review. Chemosphere 73:429-442

Maktabi S, Jamnejad A, Faramarzian K (2013) Contamination of household refrigerators by Listeria species in Ahvaz, Iran. Jundishapur J Microbiol 6:301-305

Mead PS, Slutsker L, Dietz V, McCaig LF, Bresee JS, Shapiro C (1999) Food-related illness and death in the United States. Emerg Infect Dis 5:607-625

Medrano-Felix A, Martinez C, Castro-del Campo N, Leon-Felix J, Peraza-Garay F, Gerba CP, Chaidez C (2011) Impact of prescribed cleaning and disinfectant use on microbial contamination in the home. J Appl Microbiol 110:463-471

Mensah-Attipoe J, Reponen T, Salmela A, Veijalainen A-M, Pasanen P (2015) Susceptibility of green and conventional building materials to microbial growth. Indoor Air 25:273-284

Menu E, Criscuolo A, Desnos-Ollivier M, Cassagne C, Ranque S, Berger P, Dromer F (2019) Saprochaete clavata outbreak in a hematology unit in Marseille, France. J Fungi 5(95):333-334. https://doi.org/10. 3390/jof5040095

Merrettig-Bruns U, Jelen E (2009) Anaerobic biodegradation of detergent surfactants. Materials (Basel) 2:181-206

Moat J, Rizoulis A, Fox G, Upton M (2016) Domestic shower hose biofilms contain fungal species capable of causing opportunistic infection. J Water Health 14:727-737

Monod M, Capoccia S, Léchenne B, Zaugg C, Holdom M, Jousson O (2002) Int J Med Microbiol 292(5-6):405-419, Secreted proteases from pathogenic fungi.

Munk S, Johansen C, Stahnke LH, Adler-Nissen J (2001) Microbial survival and odour in laundry. J Surfactant Deterg 4:385-394

Narancic T, O'Connor KE (2019) Plastic waste as a global challenge: are biodegradable plastics the answer to the plastic waste problem? Microbiology 165:129-137

Neilands JB (1993) Siderophores. Arch Biochem Biophys 302:1-3

Noris F, Siegel JA, Kinney KA (2011) Evaluation of HVAC filters as a sampling mechanism for indoor microbial communities. Atmos Environ 45:338-346. https://doi.org/10.1016/j.atmosenv.2010.10. 017

Nosanchuk JD, Stark RE, Casadevall A (2015) Fungal melanin: what do we know about structure? Front Microbiol 6:1463. https://doi.org/ 10.3389/fmicb.2015.01463

Novak Babič M, Zalar P, Ženko B, Schroers HJ, Džeroski S, GundeCimerman N (2015) Candida and Fusarium species known as opportunistic human pathogens from customer-accessible parts of residential washing machines. Fungal Biol 119:95-113

Novak Babič M, Zupančič J, Zalar P, Gunde-Cimerman N (2016a) Tap water transmitted establishment of pathogenic microorganisms in household appliances. In: European Committee for the Study of Corrosion and Protection of Pipe and Pipeline Systems, Ljubljana, Slovenia, May 18th-19th, $9 \mathrm{p}$

Novak Babič M, Zalar P, Ženko B, Džeroski S, Gunde-Cimerman N (2016b) Yeasts and yeast-like fungi in tap water and groundwater, and their transmission to household appliances. Fungal Ecol 20:30 39

Novak Babič M, Gunde-Cimerman N, Vargha M, Tischner Z, Magyar D, Veríssimo C, Sabino R, Viegas C, Meyer W, Brandão J (2017a) Fungal contaminants in drinking water regulation? A tale of ecology, exposure, purification and clinical relevance. Int J Environ Res Public Health 14(6):636. https://doi.org/10.3390/ijerph14060636

Novak Babič M, Zupančič J, Gunde-Cimerman N, Zalar P (2017b) Yeast in anthropogenic and polluted environments. In: Buzzini $\mathrm{P}$, Lachance MA, Yurkov A (eds) Yeasts in Natural Ecosystems: Diversity. Springer, Cham

Novikova N, De Boever P, Poddubko S, Deshevaya E, Polikarpov N, Rakova N, Coninx I, Mergeay M (2006) Survey of environmental biocontamination on board the International Space Station. Res Microbiol 157:5-12

NSF International (2013) NSF International Household Germ Study. The Public Health and Safety Organization, 3 p: http://www.nsf.org/ newsroom_pdf/2013_germ_study_FOR-WEB-ONLY.pdf (November, 2019)

Ojima M, Toshima Y, Koya E, Ara K, Tokuda H, Kawai S, Kasuga F, Ueda N (2002) Hygiene measures considering actual distributions of microorganisms in Japanese households. J Appl Microbiol 93:800 809

Panagea S, Winstanley C, Walshaw MJ, Ledson MJ, Hart CA (2005) Environmental contamination with an epidemic strain of 
Pseudomonas aeruginosa in a Liverpool cystic fibrosis centre, and study of its survival on dry surfaces. J Hosp Infect 9:102-107

Patcas R, Zbinden R, Schätzle M, Schmidlin PR, Zehnder M (2018) Whisky, microwave or hairdryer? Exploring the most efficient way to reduce bacterial colonisation on contaminated toothbrushes. Br Dent J 225(11):1007-1010. https://doi.org/10.1038/sj.bdj.2018. 1030

Percival LS, Yates VM, Williams WD, Chalmers RM, Gray FN (2014) Microbiology of Waterborne Diseases, 2nd edn. Elsevier, Oxford

Pérez-Garza J, García S, Heredia N (2017) Removal of Escherichia coli and Enterococcus faecalis after hand washing with antimicrobial and nonantimicrobial soap and persistence of these bacteria in rinsates. J Food Prot 80:1670-1675

Perry C, Marshall R, Jones E (2001) Bacterial contamination of uniforms. J Hosp Infect 48:238-241

Ponizovskaya VB, Rebrikova NL, Kachalkin AV, Antropova AB, Bilanenko EN, Mokeeva VL (2019) Micromycetes as colonizers of mineral building materials in historic monuments and museums. Fungal Biol 123:290-306

Prenafeta-Boldu FX, Summerbell R, de Hoog GS (2006) Fungi growing on aromatic hydrocarbons: biotechnology's unexpected encounter with biohazard? FEMS Microbiol Rev 30:109-130

Raghupathi PK, Zupančič J, Brejnrod AD, Jacquiod S, Houf K, Burmølle M, Gunde-Cimerman N, Sørensen SJ (2018) Microbial diversity and putative opportunistic pathogens in dishwasher biofilm communities. Appl Environ Microbiol 84(5):e02755-e02717. https://doi. org/10.1128/AEM.02755-17

Rehberg L, Frontzek A, Melhus Å, Bockmühl DP (2017) Prevalence of $\beta$-lactamase genes in domestic washing machines and dishwashers and the impact of laundering processes on antibiotic resistant bacteria. J Appl Microbiol 123:1396-1406

Richardson M, Rautemaa-Richardson R (2019) Exposure to Aspergillus in home and healthcare facilities' water environments: focus on biofilms. Microorganisms 7(1):7. https://doi.org/10.3390/ microorganisms 7010007

Rintala H, Pitkaranta M, Toivola M, Paulin L, Nevalainen A (2008) Diversity and seasonal dynamics of bacterial community in indoor environment. BMC Microbiol 8:56. https://doi.org/10.1186/14712180-8-56

Rintala H, Pitkaranta M, Taubel M (2012) Microbial communities associated with house dust. Adv Appl Microbiol 78:75-120. https://doi. org/10.1016/B978-0-12-394805-2.00004-X

Robert VA, Casadevall A (2009) Vertebrate endothermy restricts most fungi as potential pathogens. J Infect Dis 200:1623-1626

Rossi ME, Scapin D, Tondo CE (2013) Survival and transfer of microorganisms from kitchen sponges to surfaces of stainless steel and polyethylene. J Infect Dev Crit 7:229-234

Rozman U, Fijan S, Sostar Turk S, Mlakar V (2013) Real-time polymerase chain reaction for quantitative assessment of common pathogens associated with healthcare acquired infections on hospital textiles. Text Res J 83:2032-2041

Rutherford JC (2014) The emerging role of urease as a general microbial virulence factor. PLoS Path 10

Santo CE, Morais PV, Grass G (2010) Isolation and characterization of bacteria resistant to metallic copper surfaces. Appl Environ Microbiol 76:1341-1348

Sasahara T, Hayashi S, Morisawa Y, Sakihama T, Yoshimura A, Hirai Y (2011) Bacillus cereus bacteremia outbreak due to contaminated hospital linens. Eur J Clin Microbiol Infect Dis 30:219-226

Schaffner DW, Jensen D, Gerba CP, Shumaker D, Arbogast JW (2018) Influence of soap characteristics and food service facility type on the degree of bacterial contamination of open, refillable bulk soaps. J Food Prot 81:218-225

Schmaler-Ripcke J, Sugareva V, Gebhardt P, Winkler R, Kniemeyer O, Heinekamp T, Brakhage AA (2009) Production of pyomelanin, a second type of melanin, via the tyrosine degradation pathway in
Aspergillus fumigatus. Appl Environ Microbiol 75(2):493-503. https://doi.org/10.1128/AEM.02077-08

Schmithausen RM, Sib E, Exner M, Hack S, Rösing C, Ciorba P, Bierbaum G, Savin M, Bloomfield SF, Kaase M, Jacobshagen A, Gemein S, Gebel J, Engelhart S, Exner D (2019) The washing machine as a reservoir for transmission of extended-spectrumbetalactamase (CTX-M-15)-producing Klebsiella oxytoca ST201 to newborns. Appl Environ Microbiol 85:e01435-e01419. https:// doi.org/10.1128/AEM.01435-19

Schnitzler N, Peltroche-Llacsahuanga H, Bestier N, Zündorf J, Lütticken R, Haase G (1999) Effect of melanin and carotenoids of Exophiala (Wangiella) dermatitidis on phagocytosis, oxidative burst, and killing by human neutrophils. Infect Immun 67(1):94-101

Science Advice for Policy by European Academies (SAPEA) (2019) A scientific perspective on microplastics in nature and society SAPEAEvidence Review Report. SAPEA, Berlin

Seyedmousavi S, Badali H, Chlebicki A, Zhao J, Prenafeta-Boldú FX, De Hoog GS (2011) Exophiala sideris, a novel black yeast isolated from environments polluted with toxic alkyl benzenes and arsenic. Fungal Biol 115:1030-1037

Shah AA, Hasan F, Hameed A, Ahmed S (2008) Biological degradation of plastics: a comprehensive review. Biotechnol Adv 26:246-265

Shan Y, Wu W, Fan W, Haahtela T, Zhang G (2019) House dust microbiome and human health risks. Int Microbiol 22(3):297-304. https://doi.org/10.1007/s10123-019-00057-5

Silva MG, Schrank A, Bailão EF, Bailão AM, Borges CL, Staats CC, Parente JA, Pereira M, Salem-Izacc SM, Mendes-Giannini MJ, Oliveira RM, Silva LK, Nosanchuk JD, Vainstein MH, de Almeida Soares CM (2011) The homeostasis of iron, copper, and zinc in Paracoccidioides brasiliensis, Cryptococcus neoformans var. grubii, and Cryptococcus gattii: a comparative analysis. Front Microbiol 2:49. https://doi.org/10.3389/fmicb.2011.00049

Silveira F, Nucci M (2001) Emergence of black moulds in fungal disease: epidemiology and therapy. Curr Opin Infect Dis 14(6):679-684

Sinclair RG, Gerba CP (2011) Microbial contamination in kitchens and bathrooms of rural Cambodian village households. Lett Appl Microbiol 52:144-149

Singaravelu K, Gácser A, Nosanchuk JD (2014) Genetic determinance of virulence - Candida parapsilosis. Rev Iberoam Micol 31:16-21

Slepecky RA, Starmer WT (2009) Phenotypic plasticity in fungi: a review with observations on Aureobasidium pullulans. Mycologia 101: 823-832

Smaoui S, Hlima HB (2012) Effects of parabens and isothiazolinone on the microbiological quality of baby shampoo: the challenge test. Biocontrol Sci 17:135-142

Song Y, Laureijssen-van de Sande WWJ, Moreno LF, Gerrits van den Ende B, Li R, de Hoog S (2017) Comparative ecology of capsular Exophiala species causing disseminated infection in humans. Front Microbiol 8:2514. https://doi.org/10.3389/fmicb.2017.02514

Ståhl Wernersson E, Johansson E, Håkanson H (2004) Crosscontamination in dishwashers. J Hosp Infect 56:312-317

Stapleton K, Hill K, Day K, Perry JD, Dean JR (2013) The potential impact of washing machines on laundry malodour generation. Lett Appl Microbiol 56:299-306

SURS (2020) Opremljenost gospodinjstev s trajnimi potrošnimi dobrinami. Statistični urad Republike Slovenije, 1 p: https://www. stat.si/StatWeb/News/Index/8706 (March 2020)

Szczotko M, Stankiewicz A, Jamsheer-Bratkowska M (2016) Evaluation of susceptibility of polymer and rubber materials intended into contact with drinking water on biofilm formation. Rocz Panstw Zakl Hig 67:409-417

Szewzyk U, Szewzyk R, Manz W, Schleifer KH (2000) Microbiological safety of drinking water. Ann Rev Microbiol 54:81-127

Tanaka K, Katoh T, Irimajiri J, Taniguchi H, Yokozeki H (2006) Preventive effects of various types of footwear and cleaning methods on dermatophyte adhesion. J Dermatol 33:528-536 
Taubel M, Rintala H, Pitkäranta M, Paulin L, Laitinen S, Pekkanen J, Hyvärinen A, Nevalainen A (2009) The occupant as a source of house dust bacteria. J Allergy Clin Immunol 124:834-840 e847. https://doi.org/10.1016/j.jaci.2009.07.045

Tringe SG, Zhang T, Liu X, Yu Y, Lee WH, Yap J, Yao F, Suan ST, Ing SK, Haynes M, Rohwer F, Wei CL, Tan P, Bristow J, Rubin EM, Ruan Y (2008) The airborne metagenome in an indoor urban environment. PLoS One 3(4):e1862. https://doi.org/10.1371/journal. pone. 0001862

Tsiaprazi-Stamou A, Monfort IY, Romani AM, Bakalis S, Gkatzionis K (2019) The synergistic effect of enzymatic detergents on biofilm cleaning from different surfaces. Biofouling 35:883-899

Tyski S, Bocian E, Zawistowska A, Mrówka A, Kruszewska H, Grzybowska W, Zareba T (2013) Microbiological characteristics of selected liquid soaps for hands washing. Med Dosw Mikrobiol 65:207-226

US EPA (2009) National primary drinking water regulations, contaminant. United States Environmental Protection Agency, New York

US EPA (2018) Edition of the Drinking Water Standards and Health Advisories Tables. United States Environmental Protection Agency, New York

Valster MR (2011) Free-living protozoa in drinking water supplies: community composition and role as hosts for Legionella pneumophila. PhD Thesis, University of Wageningen, Wageningen, The Netherlands

van Baarlen P, van Belkum A, Summerbell RC, Crous PW, Thomma BP (2007) Molecular mechanisms of pathogenicity: how do pathogenic microorganisms develop cross-kingdom host jumps? FEMS Microbiol Rev 31:239-277

van Burik JAH, Magee PT (2001) Aspects of fungal pathogenesis in humans. Annu Rev Microbiol 55:743-772

Walton JD (1996) Host-selective toxins: agents of compatibility. Plant Cell 8:1723-1733

Wang H, Masters S, Edwards MA, Falkinham JO 3rd, Pruden A (2014) Effect of disinfectant, water age, and pipe materials on bacterial and eukaryotic community structure in drinking water biofilm. Environ Sci Technol 48(3):1426-1435. https://doi.org/10.1021/es402636u

Wang X, Cai W, van den Ende AHGG, Zhang J, Xie T, Xi L, Li X, Sun J, de Hoog GS (2018) Indoor wet cells as a habitat for melanized fungi, opportunistic pathogens on humans and other vertebrates. Sci Rep 8(1):7685. https://doi.org/10.1038/s41598-018-26071-7

Warscheid T, Braams J (2000) Biodeterioration of stone: a review. Int Biodeterior Biodegradation 46:343-368
Weikl F, Tischer C, Probst AJ, Heinrich J, Markevych I, Jochner S, Pritsch K (2016) Fungal and bacterial communities in indoor dust follow different environmental determinants. PLoS One 11: e0154131. https://doi.org/10.1371/journal.pone.0154131

Westfall C, Flores-Mireles AL, Robinson JI, Lynch AJL, Hultgren S, Henderson JP, Levin PA (2019) The widely used antimicrobial triclosan induces high levels of antibiotic tolerance in vitro and reduces antibiotic efficacy up to 100 -fold in vivo. Antimicrob Agents Chemother 63(5):e02312-e02318. https://doi.org/10.1128/AAC. 02312-18

WHO (2011) Guidelines for drinking water quality, 4th edn. World Health Organization, Geneva

Wurzbacher C, Kerr J, Grossart HP (2011) Aquatic fungi. In: Grillo O, Venora $\mathrm{G}$ (eds) The dynamical processes of biodiversity: case studies of evolution and spatial distribution. InTech, Rijeka, pp 227-258

Zajc J, Gostinčar C, Černoša A, Gunde-Cimerman N (2019) Stresstolerant yeasts: opportunistic pathogenicity versus biocontrol potential. Genes (Basel) 10(1):42. https://doi.org/10.3390/ genes 10010042

Zalar P, Novak M, De Hoog GS, Gunde-Cimerman N (2011) Dishwashers - a man-made ecological niche accommodating human opportunistic fungal pathogens. Fungal Biol 115:997-1007

Zhao J, Zeng J, de Hoog GS, Attili-Angelis D, Prenafeta-Boldú FX (2010) Isolation and identification of black yeasts by enrichment on atmospheres of monoaromatic hydrocarbons. Microb Ecol 60(1):149-156. https://doi.org/10.1007/s00248-010-9651-4

Zupančič J, Novak Babič M, Zalar P, Gunde-Cimerman N (2016) The black yeast Exophiala dermatitidis and other selected opportunistic human fungal pathogens spread from dishwashers to kitchens. PLoS ONE 11:e0148166

Zupančič J, Raghupathi PK, Houf K, Burmølle M, Sørensen SJ, GundeCimerman N (2018) Synergistic interactions in microbial biofilms facilitate the establishment of opportunistic pathogenic Fungi in household dishwashers. Front Microbiol 9:21. https://doi.org/10. 3389/fmicb.2018.00021

Zupančič J, Turk M, Črnigoj M, Ambrožič Avguštin J, Gunde-Cimerman $\mathrm{N}$ (2019) The dishwasher rubber seal acts as a reservoir of bacteria in the home environment. BMC Microbiol 19:300

Publisher's note Springer Nature remains neutral with regard to jurisdictional claims in published maps and institutional affiliations. 